\title{
Long-range Transboundary Atmospheric Transport of Polycyclic Aromatic Hydrocarbons, Carbonaceous Compositions, and Water-soluble Ionic Species in Southern Thailand
}

\author{
Chomsri ChooChuay $^{1}$, Siwatt Pongpiachan ${ }^{2 *}$, Danai Tipmanee ${ }^{3}$, Woranuch Deelaman ${ }^{1}$, \\ Oramas Suttinun ${ }^{1}$, Qiyuan Wang ${ }^{4}$, Li Xing ${ }^{4}$, Guohui Li $^{4}$, Yongming Han ${ }^{4}$, Jittree Palakun ${ }^{5}$, \\ Saran Poshyachinda ${ }^{6}$, Suparerk Aukkaravittayapun ${ }^{6}$, Vanisa Surapipith ${ }^{6}$, Junji Cao ${ }^{4}$
}

\author{
${ }^{1}$ Faculty of Environmental Management, Prince of Songkla University Hat-Yai Campus, Songkla 90112, Thailand \\ ${ }^{2}$ NIDA Center for Research \& Development of Disaster Prevention \& Management, School of Social and Environmental \\ Development, National Institute of Development Administration (NIDA), Bangkok 10240, Thailand \\ ${ }^{3}$ Faculty of Technology and Environment, Prince of Songkla University, Phuket 83120, Thailand \\ ${ }^{4}$ SKLLQG and Key Lab of Aerosol Chemistry \& Physics, Institute of Earth Environment, Chinese Academy of Sciences \\ (IEECAS), Xi'an 710061, China \\ ${ }^{5}$ Faculty of Education, Valaya Alongkorn Rajabhat University under the Royal Patronage (VRU), Pathumthani 13180, \\ Thailand \\ ${ }^{6}$ National Astronomical Research Institute of Thailand (Public Organization), Chiang-Mai 50180, Thailand
}

\begin{abstract}
This study investigated atmospheric particulate matter (PM) with an aerodynamic diameter of $<2.5 \mu$ m $\left(\mathrm{PM}_{2.5}\right)$ observed at the Prince of Songkla University (Phuket Campus) in southern Thailand. All samples $(n=75)$ were collected using MiniVol ${ }^{\mathrm{TM}}$ portable air samplers from March 2017 to February 2018. Carbonaceous aerosol compositions, i.e., organic carbon (OC) and elemental carbon (EC), water-soluble ionic species (WSIS), and polycyclic aromatic hydrocarbons (PAHs) in the $\mathrm{PM}_{2.5}$ samples were identified and quantified. We found that the average $\mathrm{PM}_{2.5}$ concentration was $42.26 \pm 13.45 \mu \mathrm{g} \mathrm{m}{ }^{-3}$, while the average concentrations of $\mathrm{OC}$ and $\mathrm{EC}$ were $3.05 \pm 1.70$ and $0.63 \pm 0.58 \mu \mathrm{g} \mathrm{m}^{-3}$, respectively. The OC/EC ratio was in the range of 2.69-16.9 (mean: 6.05 \pm 2.70 ), and the average concentration of 10 selected ions was $6.91 \pm 3.54 \mu \mathrm{g} \mathrm{m}^{-3}$. The average concentration of $\mathrm{SO}_{4}{ }^{2-}$ was the highest throughout the entire study period $\left(2.33 \pm 1.73 \mu \mathrm{g} \mathrm{m} \mathrm{m}^{-3}\right)$; the average contribution of $\mathrm{SO}_{4}{ }^{2-}$ to the major ionic components was $34 \%$. Surprisingly, the average concentrations of $\mathrm{NO}_{3}{ }^{-}$and $\mathrm{NH}_{4}{ }^{+}$ were relatively low. The mean ratio of $\left[\mathrm{NO}_{3}{ }^{-}\right] /\left[\mathrm{SO}_{4}{ }^{2-}\right]$ was $0.33 \pm 0.24$. Strong positive correlation was found between $\mathrm{K}^{+}$ and both OC and EC ( $r=0.90$ and $r=0.93$, respectively). It is also precious to highlight that biomass burning (BB) is the major source of $\mathrm{OC}, \mathrm{EC}$ and $\mathrm{K}^{+}$, which multiple studies have confirmed that the role of $\mathrm{K}^{+}$as a biomass marker. Results showed that BB episodes might play a major role in producing the observed high levels of OC. The relatively high abundance of both $\mathrm{B}[\mathrm{g}, \mathrm{h}, \mathrm{i}] \mathrm{P}$ and Ind suggests that motor vehicles, petroleum/oil combustion, and industrial waste burning are the primary emission sources of PAHs in the ambient air of Phuket. Interestingly, principal component analysis (PCA) indicated that vehicular exhausts are the main source of carbonaceous aerosol compositions found in the ambient air of Phuket, whereas the contributions of biomass burning, diesel emissions, sea salt aerosols and industrial emissions were also important.
\end{abstract}

Keywords: $\mathrm{PM}_{2.5}$; PAHs; Carbonaceous compositions; Water soluble ionic species; Biomass burning.

\section{INTRODUCTION}

Although air pollution is primarily an urban phenomenon, it is an important problem globally. In population centres

\footnotetext{
* Corresponding author.

Tel.: 00662727 3113; Fax: 006627320276

E-mail address: pongpiajun@gmail.com
}

such as Thailand, large quantities of fuel are consumed in various economic sectors, for e.g., industry (Gocht et al., 2001; Vicente and Alves, 2018; Salma et al., 2020), transportation (Silva, 2005; Zhang et al., 2014; Lin et al., 2019), and electricity generation (Dung, 1996; Chen et al., 2020). Combustion of fossil fuels such as coal and petroleum is responsible for causing the majority of air pollution (Sookkai et al., 2000; Vicente and Alves, 2018; Salma et al., 2020). Air pollution in the form of dust, especially particulate matter (PM) with an aerodynamic diameter of $<2.5 \mu \mathrm{m}\left(\mathrm{PM}_{2.5}\right)$, is 
among the most dangerous. This is because it can affect the human respiratory system (Wheeler et al., 2006; Doiron et al., 2019; Lelieveld et al., 2019; Nhung et al., 2019), exacerbating conditions such as bronchitis, influenza, pneumonia, emphysema, and asthma, especially in children, the elderly, and people with underlying cardiopulmonary/respiratory diseases (Jinsart et al., 2002; Cohen et al., 2017; Lelieveld et al., 2019).

Carbonaceous aerosols have been studied thoroughly over recent decades because they can affect human health, ecosystems, and the climate system (Shih et al., 2008; Chen et al., 2017; Pani et al., 2018). Another major concern is that they are persistent organic pollutants that can remain in the environment for long periods (Jones and Voogt, 1999; Dachs and Eisenreich, 2000; Al-Mulali et al., 2015; Bakirtas and Akpolat, 2018). Several studies have investigated the presence of carcinogenic and/or mutagenic substances in the atmosphere, derived via gas-particle partitioning, e.g., polycyclic aromatic hydrocarbons (PAHs) and polychlorinated biphenyls, the origin of which is incomplete combustion attributable to both natural and anthropogenic sources (Zhang et al., 2014; Achten and Andersson, 2015; Wincent et al., 2016; Bocchi et al., 2017; Idowu et al., 2019). These substances, which are classified as semi-volatile compounds, can be released as solid material or vapour that can adhere to the surface of other particles (Smith and Harrison, 1998; Jones and Voogt, 1999; Dachs and Eisenreich, 2000; Schummer et al., 2010; Lawal, 2017). Thus, they can spread from their source via many media, posing a danger to human health and the ecosystem. Therefore, measurement of the concentration of these carbonaceous aerosols is highly important.

Over the past few decades, BB and traffic emissions have been extensively evaluated in the northern and central parts of Thailand its release large amounts of particulate matter, including, OC-EC, WSIS and PAHs that increased environmental pollution (Chaiyo et al., 2011, 2013; Duangkaew et al., 2013; Pongpiachan, 2013; Pongpiachan et al., 2013; Tsai et al., 2013; Chaiyo and Garivait, 2014; Pongpiachan et al., 2014a, b; Janta and Chantara, 2017; Pongpiachan et al., 2017; Pani et al., 2018; Thepnuan et al., 2019; Choochuay et al., 2020). In Thailand, information on PAHs, carbonaceous compositions, i.e., organic carbon (OC) and elemental carbon (EC), and water-soluble ionic species (WSIS) in the ambient air of southern parts of the country is rare. Previous study of carbonaceous aerosols in the coastal city of Hat-Yai (southern Thailand) found that aged marine aerosols from long-range transportation and/or particles from biomass burning (BB) made a major contribution to the carbonaceous aerosols measured at the top of a building in the study area (Pongpiachan et al., 2009, 2013). Therefore, this study selected an observation site at the Prince of Songkla University (Phuket Campus) in southern Thailand to investigate atmospheric $\mathrm{PM}_{2.5}$. Phuket is the largest island in Thailand. It is located in the south and encircled by the Andaman Sea. It has long slender shape with north-south orientation. In addition, Phuket has several other large and small satellite islands. Approximately $70 \%$ of the land area is mountainous, while the remaining $30 \%$ comprises plains. The climate of Phuket is warm and moist throughout the year.
The first unambiguous evidence that the air pollution seen frequently in fine atmospheric particles is caused by human activities became available several decades ago. Comprehension of the composition and major sources of carbonaceous aerosols is important for improving air quality. Therefore, the objective of this study was to determine the characteristics of OC, EC, WSIS, and PAHs in the $\mathrm{PM}_{2.5}$ samples obtained at the study site. The analysis focused primarily on the following: (i) characterization of the chemical compounds detected in the $\mathrm{PM}_{2.5}$ samples, (ii) statistical analysis of the chemical composition and its relation to source identification, and (iii) statistical source apportionment of the chemical composition, including OC, EC, WSIS, and PAHs.

\section{MATERIALS AND METHODS}

\section{Air Quality Observatory Sites}

The aerosol sampling campaign was undertaken at Building 6 of the Prince of Songkla University (Phuket Campus) in Thailand (Fig. 1). Phuket, the largest island in Thailand, is in the south and surrounded by the Andaman Sea. The main island has long slender shape with north-south orientation and it has several other large and small satellite islands. Around $70 \%$ of the land area is mountainous, while the remaining 30\% comprises plains. The climate of Phuket is warm and moist throughout the year. The MiniVol ${ }^{\mathrm{TM}}$ air samplers were installed on the rooftop of Building $6\left(4^{\text {th }}\right.$ Floor $)$ : $7.89318^{\circ} \mathrm{N}, 98.35209^{\circ} \mathrm{E}$ (GPS coordinates: $7^{\circ} 53^{\prime} 35.5^{\prime \prime} \mathrm{N}$, $\left.98^{\circ} 21^{\prime} 07.5^{\prime \prime} \mathrm{E}\right)$. The monitoring campaign was conducted from March 2017 to February 2018.

Samples of $\mathrm{PM}_{2.5}(n=75)$ were obtained using MiniVolTM portable air samplers (Airmetrics, USA) with 47-mm quartz filters and a flow rate of $5 \mathrm{~L} \mathrm{~min}{ }^{-1}$. All samples were collected over 72-h periods. All $\mathrm{PM}_{2.5}$ samples were stored carefully in individual petri slide dishes and refrigerated to retain their chemical composition until required for further analysis. The quartz-fibre filter samples were divided into two segments. One of the filters was analyzed for OC-EC, and the other one was analyzed for PAHs and WSIS.

\section{Chemical Analysis \\ Carbonaceous Aerosol Analyses: Organic Carbon (OC) and Elemental Carbon (EC)}

The measurements of carbonaceous aerosol compositions including calibration and quality assurance/quality control (QA/QC) processes were performed at the laboratory of the Institute of Earth Environment, Chinese Academy of Science (Xian, China). The protocols adopted were the same as reported previous by Chow et al. (2007). Normally, the OC content was considered as the sum of individual OC fractions (i.e., $\mathrm{OC} 1+\mathrm{OC} 2+\mathrm{OC} 3+\mathrm{OC} 4)$ and the $\mathrm{EC}$ content was considered as the sum of individual $\mathrm{EC}$ fractions (i.e., $\mathrm{EC} 1+\mathrm{EC} 2+\mathrm{EC} 3+\mathrm{OP}$ ), based on the IMPROVE_A thermal optical reflectance protocol (Fung et al., 2002; Chow et al., 2007).

Carbonate carbon was determined through assessment of $\mathrm{CO}_{2}$ acidification from organic samples prior to the normal carbon analysis procedure. Seven temperatures were used for different fractions. The temperature protocol was applied 
Air Quality Observatory site Map
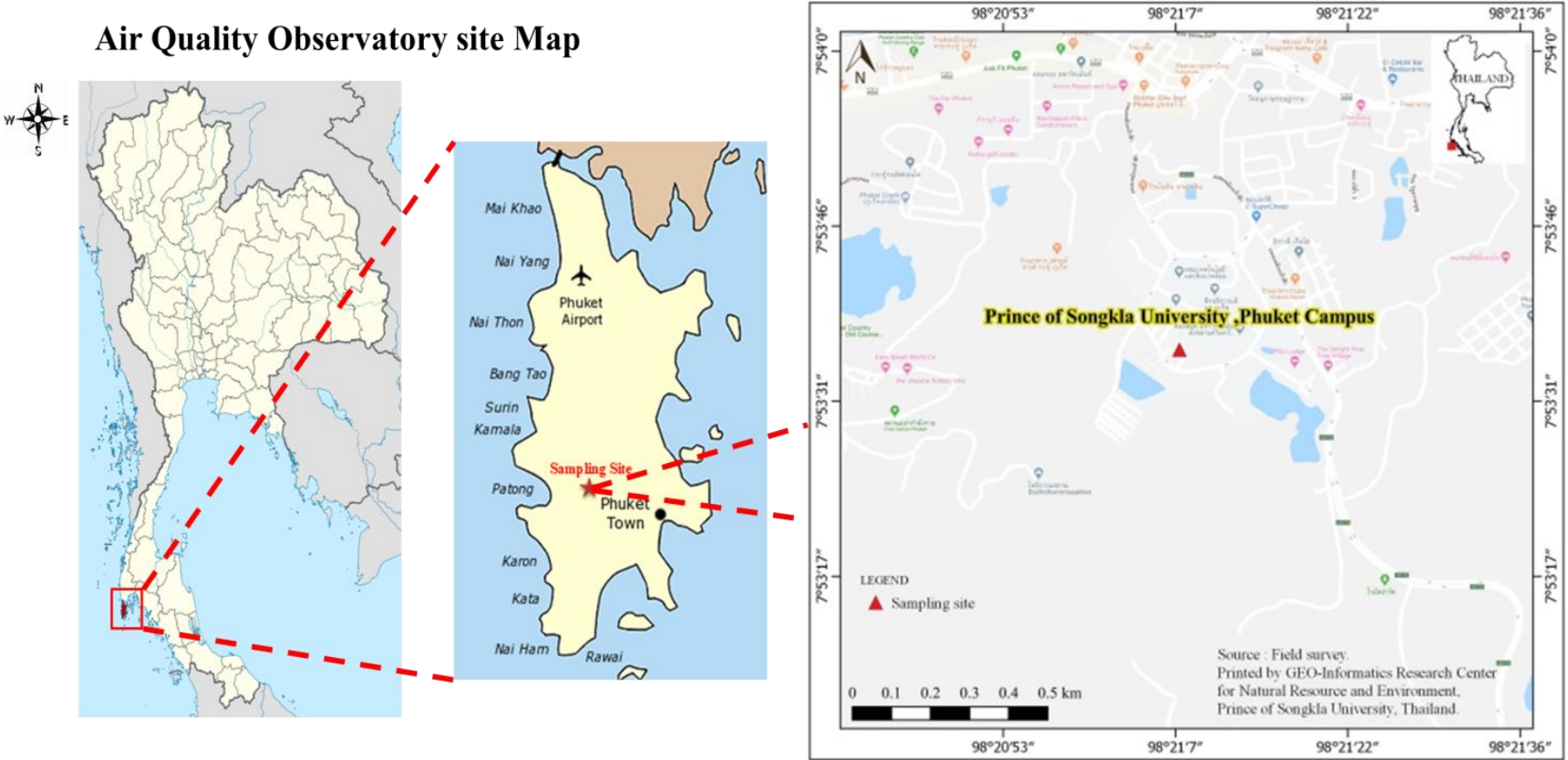

Fig. 1. Location of the sampling site used in this study.

to separate $\mathrm{OC}$ and $\mathrm{EC}$ in a process similar to the thermal optical reflectance and thermal optical transmittance pyrolysis correction. This protocol produces evaluations of total OC, total EC, and total carbon (TC), monitored by both reflectance and transmittance. For the QA/QC procedures that have been described elsewhere (Cao et al., 2003), the instrument was calibrated daily with known quantities of methane. Replicate analyses were performed for each group for 10 samples and the relative deviation of the replicate analyses was $<5 \%$ for TC and $<10 \%$ for both OC and EC.

\section{Water-soluble Ionic Species (WSIS)}

The concentrations of WSIS included five cations (i.e., $\mathrm{Na}^{+}, \mathrm{NH}_{4}^{+}, \mathrm{K}^{+}, \mathrm{Mg}^{2+}$, and $\mathrm{Ca}^{2+}$ ) and five anions (i.e., $\mathrm{Cl}^{-}, \mathrm{F}^{-}$, $\mathrm{NO}_{2}^{-}, \mathrm{NO}_{3}^{-}$, and $\mathrm{SO}_{4}{ }^{2-}$ ). An ion chromatograph with a separation column was used for the extraction from all $\mathrm{PM}_{2.5}$ samples. The QA/QC procedure for this analysis required all glassware to undergo ultrasonic cleaning and oven drying at $450^{\circ} \mathrm{C}$ for approximately $6 \mathrm{~h}$. All solvents used in the analysis procedure were pesticide residue grade (Wang et al., 2005).

\section{Polycyclic Aromatic Hydrocarbons (PAHs)}

The concentrations of PAHs in the $\mathrm{PM}_{2.5}$ samples were measured using in-injection port thermal desorption coupled with gas chromatography/mass spectrometry, which quantified the concentration of 19 PAHs as non-polar organic compounds. This analytical procedure is similar to the alternative method of traditional solvent extraction followed by gas chromatography/ mass spectrometry analysis. The analytical procedures have been described in previous studies (Ho and $\mathrm{Yu}, 2004$ ).

\section{Statistical Analysis}

This study used the SPSS System for Windows Version 22 to produce descriptive statistics (minimum, maximum, mean, and standard deviation) of the measured concentrations of PAHs, carbonaceous compositions, and WSIS. We also used PCA for identification of source appointment.

\section{RESULTS AND DISCUSSION}

\section{Concentrations of Total Carbon (TC), Organic Carbon $(\mathrm{OC})$, and Elemental Carbon (EC)}

The average concentrations of each carbon fraction for OC, EC, TC, and $\mathrm{PM}_{2.5}$ in the samples from Phuket are presented in Table 1, and the concentrations of OC and EC in each individual sample are shown in Fig. 2.

Seinfeld and Pandis (2006) reported that the highest carbonaceous fraction of fine atmospheric PM is OC at 70$80 \%$, followed by EC and inorganic carbon at $5 \%$. The average concentrations of carbonaceous chemical components found in our samples are listed in Table 1. It can be seen that of the OC fractions, OC3 was the highest, followed in descending order by OC4, OC2, and OC1. For the EC fractions, EC1 was the highest, followed by EC2 and EC3. In characterizing the chemical composition of aerosols in northern Indochina in March and April 2010, Chuang et al. (2013) found OC3 to be a reasonable tracer of BB, whereas OC2 is known as a tracer of both coal combustion (Chow et al., 2004) and vehicular exhausts (Cheng et al., 2015).

In observations of ambient air throughout an entire year in Phuket, the OC fraction was found to be the major component because it is released directly into the ambient air following incomplete combustion of organic compounds (Jimenez et al., 2008). It can be emitted directly from various sources such as industrial processes and natural occurrences, e.g., BB (primary OC) or it can be formed from gas-particle partitioning in the air (secondary OC: SOC). It is well known that OC can have substantial impact on human health (Mauderly and Chow, 2008). Conversely, the EC fraction was found to be much lower than the OC fraction. 
Table 1. Concentrations of OC, EC, TC, and $\mathrm{PM}_{2.5}$ samples from Phuket, Thailand.

\begin{tabular}{llll}
\hline Species & Minimum $\left(\mu \mathrm{g} \mathrm{m}^{-3}\right)$ & Maximum $\left(\mu \mathrm{g} \mathrm{m}^{-3}\right)$ & Mean $\pm \mathrm{SD}(n=75)$ \\
\hline OC1 & 0.00 & 0.22 & $0.04 \pm 0.05$ \\
OC2 & 0.22 & 1.56 & $0.53 \pm 0.23$ \\
OC3 & 0.73 & 5.34 & $1.57 \pm 0.75$ \\
OC4 & 0.12 & 3.37 & $0.71 \pm 0.62$ \\
OC & 1.08 & 10.90 & $3.05 \pm 1.70$ \\
EC1 & 0.10 & 3.74 & $0.70 \pm 0.64$ \\
EC2 & 0.00 & 0.28 & $0.13 \pm 0.06$ \\
EC3 & 0.00 & 0.00 & $0.00 \pm 0.00$ \\
EC & 0.09 & 3.90 & $0.63 \pm 0.58$ \\
TC & 1.17 & 14.80 & $3.67 \pm 2.25$ \\
PM 2.5 & 20.07 & 91.02 & $42.26 \pm 13.45$ \\
\hline
\end{tabular}

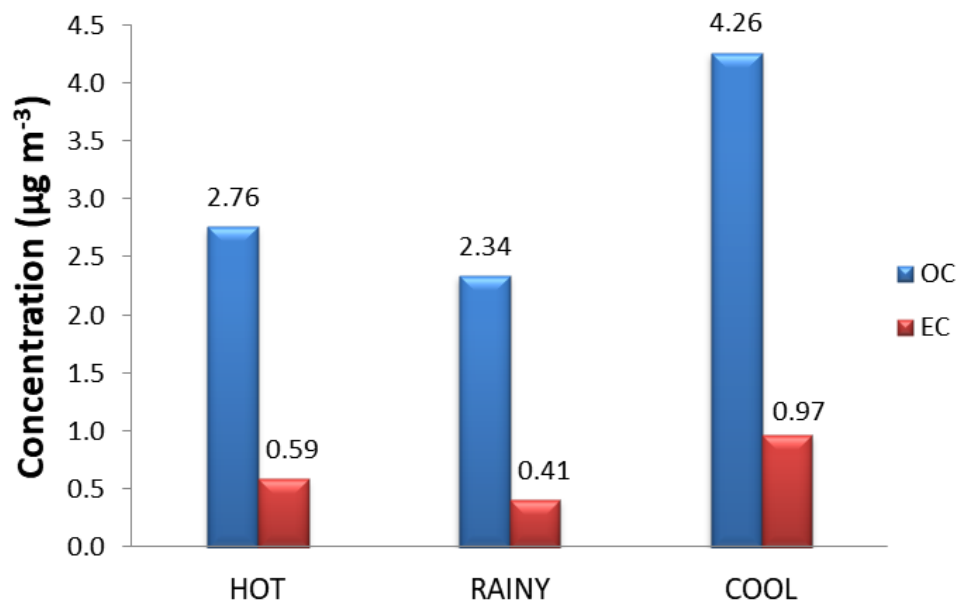

Fig. 2. Average concentration of seasonal variation of $\mathrm{OC}$ and $\mathrm{EC}$ in $\mathrm{PM}_{2.5}$ samples collected in Phuket.

As the chemical structure of EC is similar to that of impure graphite, it appears reasonable to assume that vehicular exhausts are a major source of EC. Consequently, the most important sources of EC are fossil fuel combustion and/or BB (Gelencsér, 2004).

The mean values of $\mathrm{OC}$ and $\mathrm{EC}$ in the $\mathrm{PM}_{2.5}$ samples of this study were $3.05 \pm 1.70$ and $0.63 \pm 0.58 \mu \mathrm{g} \mathrm{m}^{-3}$, respectively. These values are much smaller in comparison with those from other areas. However, the average mean concentrations of OC and EC determined in this study are similar to those reported in autumn and winter in Cape Hedo, Okinawa (Kunwar and Kawamura, 2014). Generally, EC is released from any combustion source and it is usually used as a tracer of primary OC (Turpin and Huntzicker, 1995). Hence, the relationship between OC and EC can be used to estimate the source of carbonaceous particles. The relationship between OC and EC in the $\mathrm{PM}_{2.5}$ samples obtained in Phuket in this study is illustrated in Fig. 3. The large $\mathrm{R}^{2}$ values $(0.86)$ have been found in this study indicated that the impact of local primary sources (traffic and biomass burning) have a big role in Phuket's atmosphere.

\section{OC/EC Ratios and Secondary Organic Carbon (SOC) Contributions \\ OC/EC Ratios}

Carbonaceous compounds represent a significant fraction of atmospheric aerosols, accounting for $20-35 \%$ of $\mathrm{PM}_{10}$ and $20-45 \%$ of $\mathrm{PM}_{2.5}$ (Yttri et al., 2007; Putaud et al., 2010). The OC/EC ratio is applied frequently to explain the emission sources of carbonaceous aerosol compounds (Han et al., 2007, 2009; Wu et al., 2019; Xing et al., 2020). In our study, the OC/EC ratios determined in this study were in the range of 2.69-16.9 with an annual mean value of $6.05 \pm 2.70$. The season averaged OC/EC ratios are 4.94 (hot), 6.84 (rainy), and 5.70 (cool) (Fig. 4).

The measurement of atmospheric $\mathrm{PM}_{2.5}$-bound carbonaceous aerosol composition widely studied in Thailand, especially in the northern and the central part of Thailand. In this study, the annual mean OC/EC ratios value is 1.1 times lower than the value reported from Chiang-Mai, Thailand (Choochuay et al., 2020). Most of the time previous studies the availability of data from southern Thailand is limited. The chemical characteristics of carbonaceous aerosols and PAHs of $\mathrm{PM}_{10}$ in the city of Hat-Yai in southern Thailand have been studied by Pongpiachan et al. (2014a). Their study suggested that the persistence of OC/EC ratios could have been attributable from $\mathrm{BB}$, vehicular, industrial emissions, and/or long-range transportation and agricultural waste burning aerosols. The OC/EC ratio can be used to estimate the primary sources of pollution. Several studies on carbonaceous $\mathrm{PM}$ in different parts of the world have reported that high OC/EC ratios are related to SOC (Chow et al., 1993; Turpin 


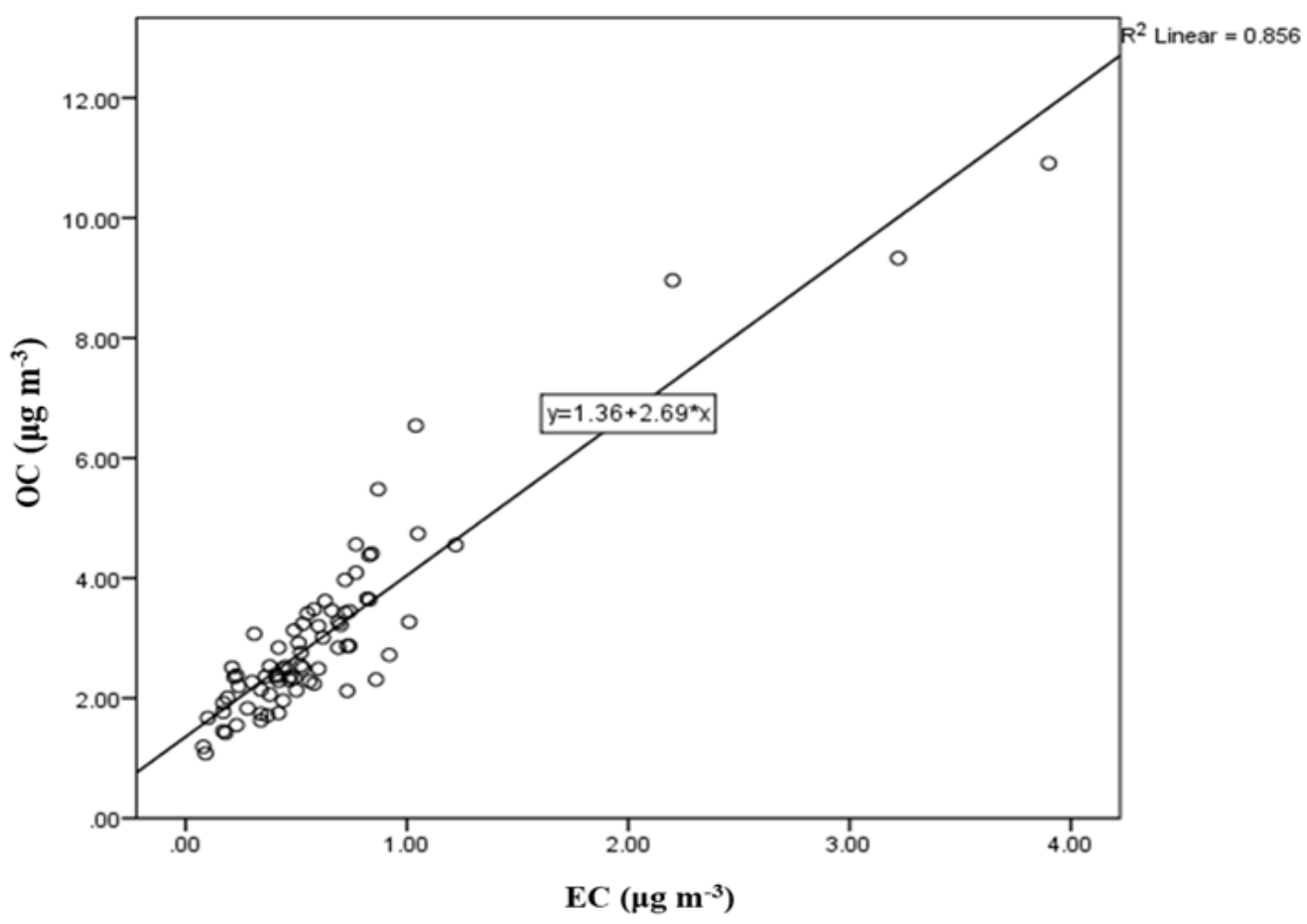

Fig. 3. EC vs. OC correlation in the $\mathrm{PM}_{2.5}$ samples collected in Phuket during March 2017 to February 2018.

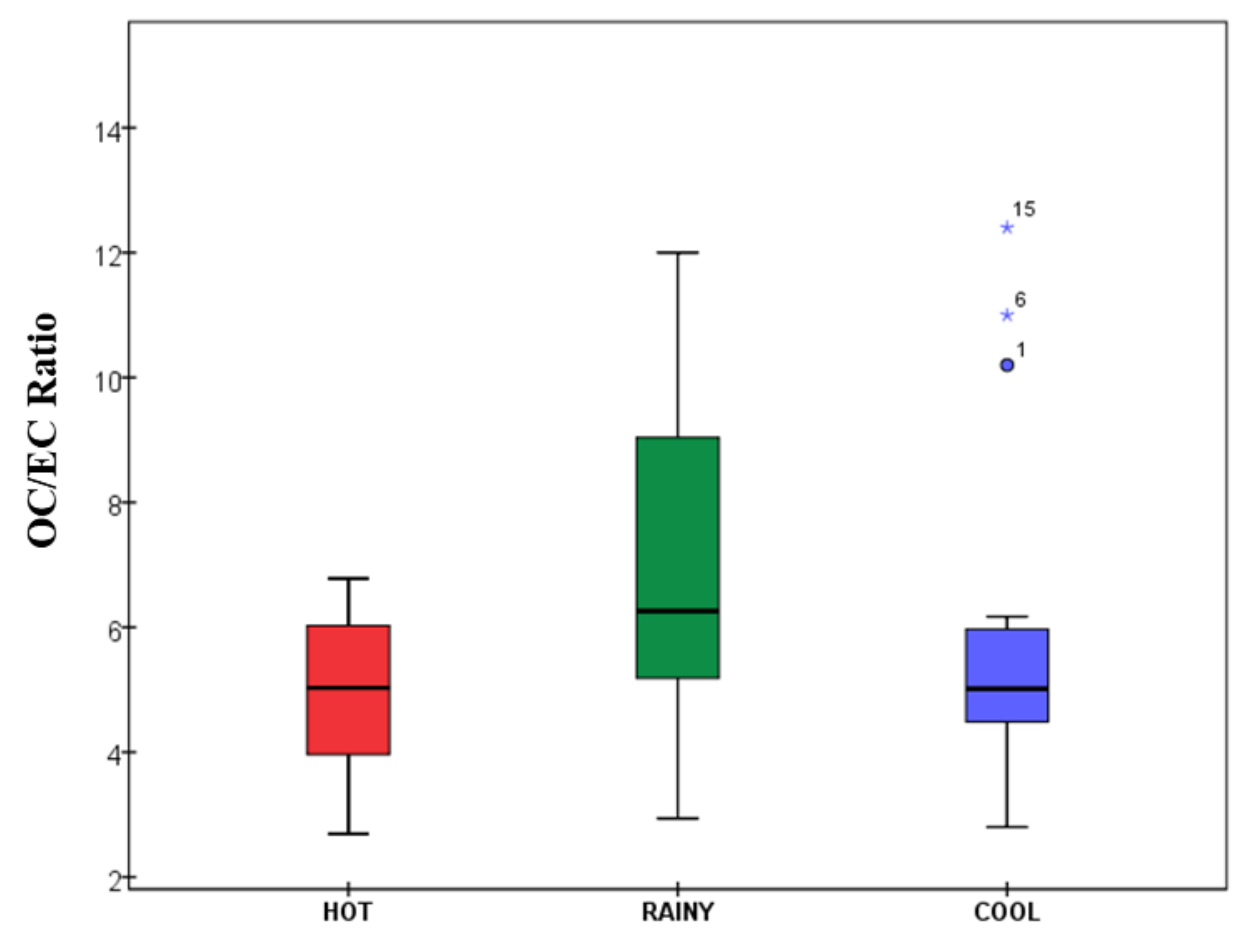

Fig. 4. The OC/EC ratios obtained in Phuket during March 2017 to February 2018.

and Huntzicker, 1995). Carbonaceous aerosols with OC/EC values $>2$ can be considered to contain significant quantities of SOC, which lager OC/EC values are also attributed to (i) biogenic emissions, (ii) BB aerosols (Wu et al., 2019; Kalita et al., 2020; Kaskaoutis et al., 2020). In this study, the range of OC/EC ratios was 2.69-16.9 (mean: $6.05 \pm 2.70$ ). However, a high value of the OC/EC ratio (12) was reported by Cao et al. (2005) in aerosols derived from residential coal combustion. The result from recent study in Southeast Asia regions (SEA) reported that the Biomass burning and biogenic emissions were significantly larger compared to other regions in south Asia (Kalita et al., 2020). However, the concentrations of carbonaceous compounds vary inter-regionally in relation to local emissions and weather (Heald et al., 2008). 


\section{Estimation of Secondary Organic Carbon (SOC)}

The SOC contribution can be estimated by measuring OC and EC concentrations and an appropriately selected primary OC to EC ratio. Many studies have used a widely accepted EC tracer method to measure SOC. Using this method, the contribution of SOC can be calculated based on the minimum values of OC/EC ratios, where EC is used as a measure of primary OC (Castro et al., 1999). In this study, SOC was estimated using the following equation:

$\mathrm{SOC}=\mathrm{OC}_{\text {total }}-\mathrm{EC} \times(\mathrm{OC} / \mathrm{EC})_{\text {pri }}$

where $\mathrm{OC}_{\text {total }}$ represents the total $\mathrm{OC}$ and $(\mathrm{OC} / \mathrm{EC})_{\text {pri }}$ is the mean of the three lowest $\mathrm{OC} / \mathrm{EC}$ ratios.

The mean of the three lowest OC/EC ratios (2.79) was applied in this study to estimate the SOC content of the $\mathrm{PM}_{2.5}$ samples. Based on this technique, it was determined that the annual mean value of SOC was $1.30 \pm 1.63 \mu \mathrm{g} \mathrm{m}^{-3}$ and the highest value was $2.82 \mu \mathrm{g} \mathrm{m}^{-3}$. The percentage contribution of SOC to $\mathrm{OC}_{\text {total }}$ was $42.6 \%$ in this study. This value is 1.4 times lower than the value $(59.2 \%)$ detected in Okinawa, Japan (Kunwar and Kawamura, 2014) and 1.5 times lower than both the value $(67.8 \%)$ reported for Hat-Yai, Thailand (Pongpiachan et al., 2014a) and the value (65\%) found in Claremont, USA (Na et al., 2004). Conversely, our value is 2.5 times higher than that observed in Birmingham, United Kingdom (Castro et al., 1999). Our result is close to that found by Li et al. (2009) in their study conducted at a coastal site $(37.7 \%)$, and similar to values observed in Kaohsiung in Taiwan (40\%) by Lin and Tai (2001). The application of diagnostic binary ratios of OC/EC and estimations of secondary organic carbon (SOC) in this study highlighted that the enhanced impacts of incomplete combustion emissions, such as motor vehicle exhaust, fuel burning, and biomass burning, which can be remained in the atmosphere for several days (Wu et al., 2019; Kaskaoutis et al., 2020).

\section{Atmospheric Concentrations of Water-soluble Ionic Species (WSIS) and PAHs in PM2.5}

Given that Phuket is the largest island in Thailand, it was considered important to examine the impact of marine aerosols on the characterization of carbonaceous compositions. The chemical characteristics of WSIS have been studied thoroughly in different areas of the world. Several studies have reported that $\mathrm{SO}_{4}{ }^{2-}$ and $\mathrm{Cl}^{-}$are the main contributors to WSIS found in marine aerosols, whereas $\mathrm{NH}_{4}{ }^{+}$and $\mathrm{K}^{+}$are the main contributors to WSIS in aerosols attributable to BB (Kocaka et al., 2007; Park and Cho, 2011).

The individual and average concentrations of 10 selected ions $\left(\mathrm{SO}_{4}{ }^{2-}, \mathrm{Na}^{+}, \mathrm{Ca}^{2+}, \mathrm{Cl}^{-}, \mathrm{NO}_{3}{ }^{-}, \mathrm{NO}_{2}^{-}, \mathrm{NH}_{4}{ }^{+}, \mathrm{K}^{+}, \mathrm{Mg}^{2+}\right.$ and $\mathrm{F}^{-}$) considered in this study are presented in Table 2 .

Several previous studies have used diagnostic ratios to analyse the sources of marine aerosols and non-marine aerosols or non-sea-salt for WSIS (Karthikeyan and Balasubramanian, 2006). Previous work has reported that the sources of $\mathrm{K}^{+}, \mathrm{SO}_{4}{ }^{2-}$, and $\mathrm{Ca}^{2+}$ are not solely from marine aerosols (Wang and Shooter, 2001). Therefore, the contribution of each of these ions from non-sea-salt sources was calculated using the following equations (Hedge et al., 2007; George et al., 2008; Behrooz et al., 2017):

nss- $\mathrm{SO}_{4}{ }^{2-}=\left(\mathrm{SO}_{4}{ }^{2-}\right)-0.2516 *\left(\mathrm{Na}^{+}\right)$

nss- $\mathrm{Ca}^{2+}=\left(\mathrm{Ca}^{2+}\right)-0.0385 *\left(\mathrm{Na}^{+}\right)$

nss- $\mathrm{K}^{+}=\left(\mathrm{K}^{+}\right)-0.037 *\left(\mathrm{Na}^{+}\right)$

*Note, nss- $\mathrm{SO}_{4}{ }^{2-}$, nss- $\mathrm{Ca}^{2+}$, and (nss- $\mathrm{K}^{+}$can be used in the formulas above, assuming that marine aerosols are the same as sea-salt in terms of chemical composition. Meanwhile, $\mathrm{Na}^{+}$has been used as a marker for marine aerosols, by assuming that whole $\mathrm{Na}^{+}$comes from the marine source. (George et al., 2008; Behrooz et al., 2017).

Based on the OC/EC ratios in this study, long-range atmospheric transport of $\mathrm{BB}$ plumes from nearby countries could represent one source. In this region, BB is a widespread activity and it is known that PM is transported from Indonesia (Southeast Asia) into southern Thailand (Phairuang et al., 2020). Moreover, strong correlation $(r=0.94)$ was found between nss- $\mathrm{K}^{+}$and $\mathrm{OC}$, which was found related to long-range atmospheric transport and the influence of $\mathrm{BB}$ on organic aerosols during the cool period.

Previous study reported that $\mathrm{SO}_{4}{ }^{2-}, \mathrm{K}^{+}$, and $\mathrm{NH}_{4}{ }^{+}$are the major fractions in the form of secondary inorganic aerosols and biomass burning. Moreover, WSIS of $\mathrm{NH}_{4}^{+}, \mathrm{K}^{+}, \mathrm{Ca}^{2+}$, $\mathrm{Na}^{+}$were extracted from the $\mathrm{PM}_{2.5}$ ambient air samples, which $\mathrm{Na}^{+}, \mathrm{NH}_{4}^{+}$, and $\mathrm{Cl}^{-}$are mainly originated from aged

Table 2. Concentrations of water-soluble ionic species (WSIS) observed in the $\mathrm{PM}_{2.5}$ samples from Phuket, Thailand.

\begin{tabular}{lllll}
\hline Ionic Species & Mean $\left(\mu \mathrm{g} \mathrm{m}^{-3}\right)$ & Min. $\left(\mu \mathrm{g} \mathrm{m}^{-3}\right)$ & Max. $\left(\mu \mathrm{g} \mathrm{m}^{-3}\right)$ & $\%$ mass of total ion content \\
\hline $\mathrm{F}^{-}$ & $0.09 \pm 0.01$ & 0.07 & 0.12 & 1 \\
$\mathrm{Cl}^{-}$ & $0.53 \pm 0.28$ & 0.32 & 2.47 & 8 \\
$\mathrm{NO}_{2}{ }^{-}$ & $0.30 \pm 0.19$ & 0.00 & 0.73 & 4 \\
$\mathrm{NO}_{3}{ }^{-}$ & $0.53 \pm 0.21$ & 0.00 & 1.62 & 8 \\
$\mathrm{SO}_{4}{ }^{-}$ & $2.33 \pm 1.73$ & 0.33 & 9.21 & 34 \\
$\mathrm{Na}^{+}$ & $1.47 \pm 0.39$ & 0.65 & 3.04 & 21 \\
$\mathrm{NH}_{4}{ }^{+}$ & $0.29 \pm 0.32$ & 0.00 & 2.38 & 4 \\
$\mathrm{~K}^{+}$ & $0.28 \pm 0.24$ & 0.00 & 1.58 & 4 \\
$\mathrm{Mg}^{2+}$ & $0.13 \pm 0.03$ & 0.06 & 0.24 & 2 \\
$\mathrm{Ca}^{2+}$ & $0.96 \pm 0.14$ & 0.66 & 1.37 & 14 \\
Total & $6.91 \pm 3.54$ & - & - & - \\
\hline
\end{tabular}


sea salt and mixed industrial, whilst $\mathrm{Mg}^{2+}$ and $\mathrm{Ca}^{2+}$ are generally made from mineral dust (Dahari et al., 2019). In this study, the average $\mathrm{SO}_{4}{ }^{2-}$ concentration was the highest throughout the entire study period for all season (Fig. 5).

As previously mentioned, the most dominant species in this study were $\mathrm{SO}_{4}{ }^{2-}, \mathrm{Na}^{+}$and $\mathrm{Ca}^{2+}$ which mainly contributed from secondary inorganic aerosols, biomass burning, sea salt and mixed industrial for the ambient air in Phuket (Dahari et al., 2019). The statistics showed that there were no obvious differences on $\mathrm{F}^{-}, \mathrm{Cl}^{-}, \mathrm{NO}_{2}^{-}$and $\mathrm{NO}_{3}{ }^{-}$in all seasons, while $\mathrm{SO}_{4}{ }^{2-}, \mathrm{Na}^{+}, \mathrm{Ca}^{2+}, \mathrm{NH}_{4}{ }^{+}, \mathrm{K}^{+}$and $\mathrm{Mg}^{2+}$ were obvious differences between rainy and cool $(p>0.05)$.

For the classification, $\left[\mathrm{NO}_{3}{ }^{-}\right] /\left[\mathrm{SO}_{4}{ }^{2-}\right]$ ratios were applied carefully to identify the incidence of stationary sources (e.g., boilers industries, power plants, etc.) and mobile sources (e.g., vehicular exhausts) of nitrogen and sulphur. They are generally formed via atmospheric reactions of their gaseous phase, e.g., $\mathrm{NO}_{x}$ and $\mathrm{SO}_{2}$. Normally, $\mathrm{SO}_{2}$ is released via coal combustion, whilst $\mathrm{NO}_{\mathrm{x}}$ results from any type of combustion, e.g., coal power plants and vehicular emissions in aerosols (Liu et al., 2011; Mkoma et al., 2014 Javid et al., 2015; Park et al., 2015; Deng et al., 2016; Huang et al., 2016). A high $\left[\mathrm{NO}_{3}{ }^{-}\right] /\left[\mathrm{SO}_{4}{ }^{2-}\right]$ ratio (1.06) was found in a region with high levels of vehicular emissions (Li et al., 2009). The mean $\left[\mathrm{NO}_{3}{ }^{-}\right] /\left[\mathrm{SO}_{4}{ }^{2-}\right]$ ratio found during the annual was $0.33 \pm$ 0.24 , while the season averaged ratios were 0.22 (hot), 0.31 (rainy), and 0.17 (cool). It is lower than that found in other areas in summer in China, e.g., Beijing (0.83), Tianjin (0.71), and Shijiazhuan (0.56) (Dao et al., 2014). Hence, this result means that the local sources from vehicular emissions (tracers for $\mathrm{NO}_{3}{ }^{-}$) are limited and the ratio decreases, as sulfate has more regional sources. The high temperatures in Phuket modulate particulate nitrate into the gaseous phase, which reduces the $\left[\mathrm{NO}_{3}{ }^{-}\right] /\left[\mathrm{SO}_{4}{ }^{2-}\right]$ ratio (Cuccia et al., 2013; Titos et al., 2014; Dumka et al., 2017). However, the ratio of $0.3-0.5$ found in this study is also lower than that usually found in China because of the widespread use of sulphurcontaining coal by the Chinese (Yao et al., 2002).

The ions $\mathrm{SO}_{4}{ }^{2-}$ and $\mathrm{NH}_{4}{ }^{+}$are secondary ions that have a complex reaction in that $\mathrm{NH}_{4}{ }^{+}$responds rapidly with $\mathrm{SO}_{4}{ }^{2-}$ to the constant form of ammonium salts (Lai et al., 2007; Li et al., 2012; Wang et al., 2013). Generally, $\mathrm{SO}_{4}{ }^{2-}$ is influenced by anthropogenic sources in industrial areas. The concentration of $\mathrm{SO}_{4}{ }^{2-}$ was significantly higher than that of $\mathrm{Na}^{+}$and $\mathrm{Cl}^{-}$, whereas nss- $\mathrm{SO}_{4}{ }^{2-}$ was the primary species for acid replacement (Zhang et al., 2010). Similar to other ions with anthropogenic sources (e.g., $\mathrm{NO}_{3}^{-}$), the correlation with those of nss- $\mathrm{SO}_{4}{ }^{2-}$ was reasonable (Zhang et al., 2010).

In general, $\mathrm{Na}^{+}$and $\mathrm{Cl}^{-}$are the sea salt ions that form the largest fractions in marine aerosols. In this study, the highest concentrations of $\mathrm{Na}^{+}$and $\mathrm{Cl}^{-}$were $1.47 \pm 0.39$ and $0.53 \pm$ $0.28 \mu \mathrm{g} \mathrm{m}^{-3}$, which accounted for $21.0 \%$ and $8.0 \%$ of the total ionic species, respectively. For marine aerosols, Zhang et al. (2010) reported that sea salt aerosols (i.e., $\mathrm{NaCl}$ ) can

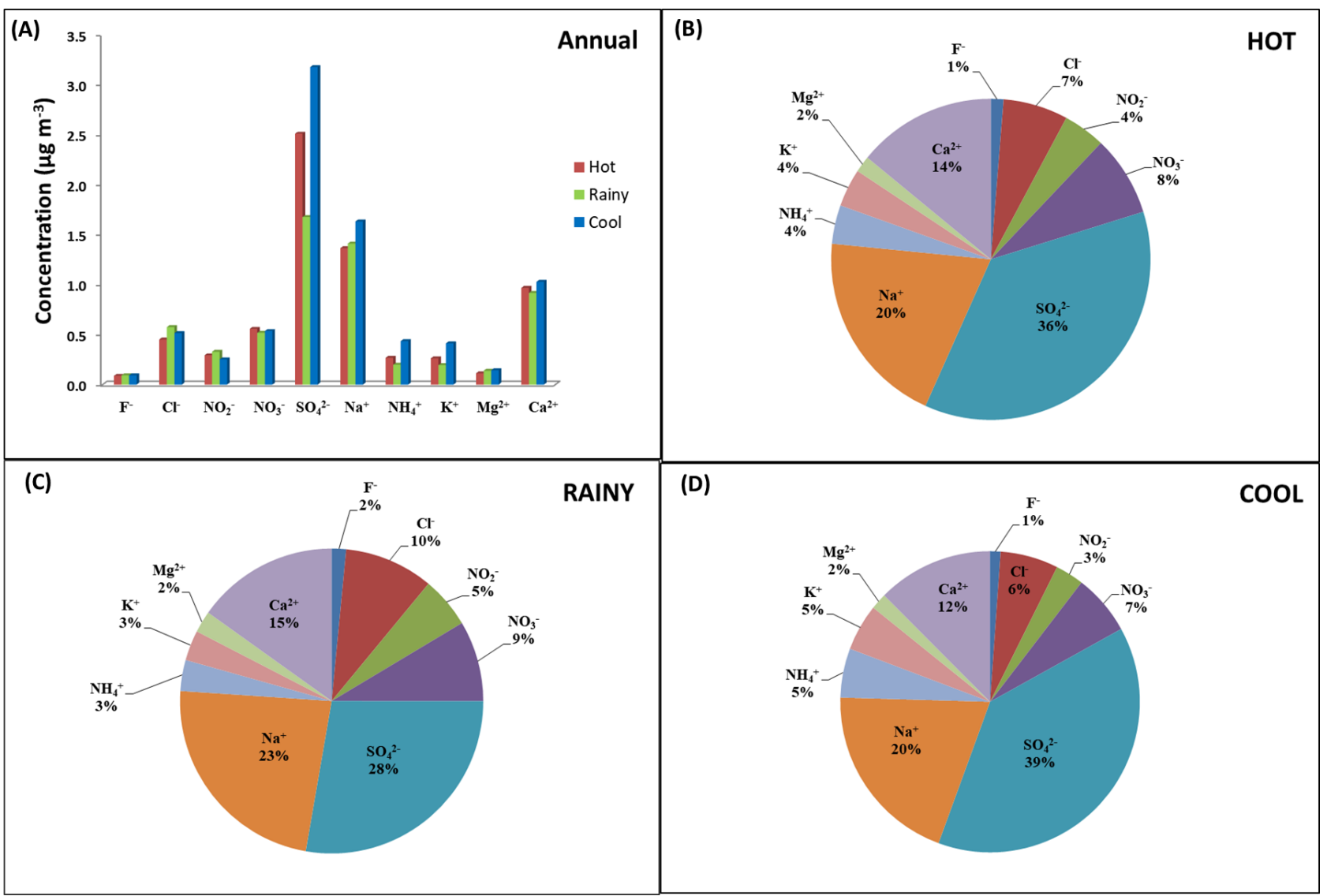

Fig. 5. (A) Annual concentration of individual WSIS, Percentage contributions of individual WSIS in (B) hot, (C) rainy and (D) cool season collected from Phuket. 
emit $\mathrm{HCl}$ via exchange with sulphuric acid and nitric acid, which results in a shortage of $\mathrm{Cl}^{-}$relative to $\mathrm{Na}^{+}$. The annual average equivalent ratios of $\mathrm{Cl}^{-} / \mathrm{Na}^{+}$in the aerosols from Phuket were 3.4 and 3.2 times lower than those on Yongxing Island and those of seawater, respectively (Table 3 ). In our study, we find that there is chloride depletion is the result of the interaction of sea salt with acidic species, nitrate, sulfate followed by the losing of $\mathrm{Cl}^{-}$in term of $\mathrm{HCl}$ gas (Stogiannidis and Laane, 2015). Moreover, the ratio of $\mathrm{Mg}^{2+}$ to $\mathrm{Na}^{+}$was 0.09 , which is 2.3 and 2.4 times lower in comparison with the values from Yongxing Island and seawater, suggesting that the ratio of $\mathrm{Mg}^{2+} / \mathrm{Na}^{+}\left(\mathrm{Mg}^{2+}\right.$ loss $)$ in $\mathrm{PM}_{2.5}$ samples maybe due to the leach of magnesium chloride $\left(\mathrm{MgCl}_{2}\right)$, which is a component of bittern in sea salt.

\section{Correlations of Chemical Composition of $\mathrm{PM}_{2.5}$ and its Relation to Source Identification}

Some ions in carbonaceous aerosol composition such as $\mathrm{K}^{+}, \mathrm{SO}_{4}{ }^{2-}$, and $\mathrm{Ca}^{2+}$ have multiple sources, e.g., ocean and land surfaces. Additionally, nss- $\mathrm{SO}_{4}{ }^{2-}$ in the atmosphere can be derived from various sources. It originates from the combustion of fossil fuels such as coal, oil, and natural gas (Cuccia et al., 2013; Kunwar and Kawamura, 2014; Titos et al., 2014; Dumka et al., 2017). In Phuket, we found the highest concentrations of carbonaceous aerosols found in $\mathrm{OC}$ and $\mathrm{SO}_{4}{ }^{2-}$ were 3.05 and $2.33 \mu \mathrm{g} \mathrm{m}^{-3}$, respectively. Several previous studies reported that $\mathrm{SO}_{4}{ }^{2-}$ and $\mathrm{Cl}^{-}$are the principal species of WSIS normally found in marine aerosols, whereas $\mathrm{K}^{+}$and $\mathrm{NH}_{4}{ }^{+}$are the primary species associated with $\mathrm{BB}$ and agricultural waste burning (Matsumoto et al., 1998; Kocaka et al., 2007; Park and Cho, 2011; Pongpiachan et al., 2014a). The correlations of OC, EC, and WSIS shown in Table 4. The results showed strong correlation between $\mathrm{K}^{+}$and both OC $(r=0.89)$ and EC $(r=0.93)$. It is well known that $\mathrm{K}^{+}$is a marker of BB (Kundu et al., 2010), whereas $\mathrm{EC}$ is a marker of incomplete combustion of biomass and/or fossil fuel. We also found strong correlation between nss- $\mathrm{K}^{+}$and both EC $(r=0.93)$ and OC $(r=0.89)$; therefore, $\mathrm{BB}$ episodes might also play a major role in generating the higher OC concentrations. Previous analysis of satellite imagery revealed evidence of frequent BB episodes in southern Thailand, e.g., in preparation for agriculture, agricultural produce burning, and forest fires.

Among the ions measured in this study, $\mathrm{NH}_{4}{ }^{+}$was strongly correlated with $\mathrm{K}^{+}(r=0.81)$. It is assumed that one effect of $\mathrm{BB}$ was significant enrichment in $\mathrm{PM}_{2.5}$. Previous studies related that fertilizer use as well as agriculture waste and related domestic activities are sources of gaseous ammonia emissions (Thepanondh et al., 2005).

\section{Concentrations of Polycyclic Aromatic Hydrocarbons (PAHs)}

The concentrations of PAHs are summarized in Table 5. The total concentration of all 19 PAHs was $0.3780 \pm$ $0.3480 \mathrm{ng} \mathrm{m}^{-3}$. The values determined in this study are lower than those measured in other areas of Thailand such as Chiang-Mai and Bangkok, which are known as heavily polluted areas (Pongpiachan, 2013; Pongpiachan et al., 2014b).

Several previous studies have investigated the environmental cycle of PAHs in different environmental situations in Thailand (Pongpiachan, 2013; Pongpiachan et al., 2014b, 2015). In northern Thailand, BB, forest fires, and agricultural waste burning during winter emit large quantities of PM into the atmosphere, especially ultra-fine particles that include $\mathrm{PM}_{2.5}$-bound PAHs (Vadrevu et al., 2015, 2019). In central Thailand, vehicular emissions represent a major contributor to atmospheric PM. However, in southern Thailand, especially Phuket, the limited availability of PAH data makes it difficult to identify the sources of the pollution emitted into the atmosphere.

The concentrations of the individual PAHs in the $\mathrm{PM}_{2.5}$ samples obtained in Phuket during March 2017 to February 2018 decreased in the following order: $\mathrm{B}[\mathrm{g}, \mathrm{h}, \mathrm{i}] \mathrm{P}>\mathrm{Ind}>\mathrm{Phe}$ $>\mathrm{B}[\mathrm{a}] \mathrm{A}>\mathrm{Cor}>\mathrm{B}[\mathrm{b}] \mathrm{F}>\mathrm{B}[\mathrm{k}] \mathrm{F}>\mathrm{B}[\mathrm{a}] \mathrm{P}>\mathrm{B}[\mathrm{e}] \mathrm{P}>$ Ace $>$ $\mathrm{D}[\mathrm{a}, \mathrm{h}] \mathrm{A}>$ Fluo $>\mathrm{Fl}>\mathrm{Pyr}>\mathrm{D}[\mathrm{a}, \mathrm{e}] \mathrm{P}>\mathrm{Chry}>\mathrm{Ant}>\mathrm{Per}>$ $\mathrm{B}[\mathrm{a}] \mathrm{F}$. Of the 16 priority PAHs identified by the United States Environmental Protection Agency, 9 are emitted via combustion processes such as those involving coal, diesel, and petroleum. Ravindra et al. (2008) reported that Flu, Pry, $\mathrm{B}[\mathrm{a}] \mathrm{A}, \mathrm{Chry}, \mathrm{B}[\mathrm{b}] \mathrm{F}, \mathrm{B}[\mathrm{k}] \mathrm{F}, \mathrm{B}[\mathrm{a}] \mathrm{P}, \mathrm{B}[\mathrm{g}, \mathrm{h}, \mathrm{i}] \mathrm{P}$, and Ind are combustion PAHs. The ratios of the concentrations of these combustion PAHs have been analysed in many studies to identify the sources of the PAHs in aerosols (Manoli et al., 2004). In this study, high abundances of $\mathrm{B}[\mathrm{g}, \mathrm{h}, \mathrm{i}] \mathrm{P}$ and Ind were detected, indicating that motor vehicles, petroleum/oil combustion, and industrial waste burning are emission sources of the PAHs found in the ambient air of Phuket (Zhou et al., 1999; Ravindra et al., 2008).

Table 3. Comparison of equivalent ratios of ionic species in aerosols observed in Phuket, on Yongxing Island (Xiao et al., 2017), and those in seawater (Keene et al., 1986).

\begin{tabular}{llll}
\hline Ion ratios & Phuket Island & Yongxing Island & Seawater \\
\hline $\mathrm{Cl}^{-} / \mathrm{Na}^{+}$ & 0.37 & 1.25 & 1.17 \\
$\mathrm{Mg}^{2+} / \mathrm{Na}^{+}$ & 0.09 & 0.21 & 0.22 \\
$\mathrm{~K}^{+} / \mathrm{Na}^{+}$ & 0.19 & 0.048 & 0.021 \\
$\mathrm{Ca}^{2+} / \mathrm{Na}^{+}$ & 0.68 & 0.62 & 0.044 \\
$\mathrm{SO}_{4}{ }^{2-} / \mathrm{Na}^{+}$ & 1.54 & 0.66 & 0.12 \\
$\mathrm{nss}^{-} \mathrm{SO}_{4}^{2-} / \mathrm{Na}^{+}$ & 1.33 & 0.54 & - \\
$\mathrm{NO}_{3}{ }^{-} / \mathrm{Na}^{+}$ & 0.37 & 0.18 & - \\
$\mathrm{NH}_{4}{ }^{+} / \mathrm{Na}^{+}$ & 0.20 & 0.022 & - \\
$\mathrm{NO}_{3}{ }^{-} / \mathrm{nss}_{-}-\mathrm{SO}_{4}{ }^{2-}$ & 0.27 & 0.34 & - \\
$\mathrm{NH}_{4}{ }^{+} / \mathrm{nss}^{-} \mathrm{Ca}^{2+}$ & 0.32 & 0.038 & - \\
\hline
\end{tabular}


Table 4. Pearson correlation analysis of OC, EC, and WSIS in $\mathrm{PM}_{2.5}$ samples obtained from Phuket during March 2017 to February 2018.

\begin{tabular}{|c|c|c|c|c|c|c|c|c|c|c|c|c|c|c|c|}
\hline & $\mathrm{F}^{-}$ & $\mathrm{Cl}^{-}$ & $\mathrm{NO}_{2}^{-}$ & $\mathrm{NO}_{3}{ }^{-}$ & $\mathrm{SO}_{4}{ }^{2-}$ & $\mathrm{Na}^{+}$ & $\mathrm{NH}_{4}{ }^{+}$ & $\mathrm{K}^{+}$ & $\mathrm{Mg}^{2+}$ & $\mathrm{Ca}^{2+}$ & $\mathrm{nss} \mathrm{SO}_{4}{ }^{2-}$ & nss-Ca ${ }^{2+}$ & $\mathrm{nss}-\mathrm{K}^{+}$ & $\mathrm{OC}$ & $\mathrm{EC}$ \\
\hline $\mathrm{F}^{-}$ & 1 & & & & & & & & & & & & & & \\
\hline $\mathrm{Cl}^{-}$ & 0.13 & 1 & & & & & & & & & & & & & \\
\hline $\mathrm{NO}_{2}^{-}$ & $0.24^{*}$ & 0.00 & 1 & & & & & & & & & & & & \\
\hline $\mathrm{NO}_{3}^{-}$ & 0.17 & 0.15 & $0.52^{* *}$ & 1 & & & & & & & & & & & \\
\hline $\mathrm{SO}_{4}{ }^{2-}$ & -0.16 & -0.07 & -0.02 & $0.55^{\text {** }}$ & 1 & & & & & & & & & & \\
\hline $\mathrm{Na}^{+}$ & -0.01 & $0.58^{* *}$ & -0.05 & $0.40^{* *}$ & $0.61^{* *}$ & 1 & & & & & & & & & \\
\hline $\mathrm{NH}_{4}{ }^{+}$ & 0.07 & -0.12 & 0.20 & $0.67^{* *}$ & $0.73^{* *}$ & $0.27^{*}$ & 1 & & & & & & & & \\
\hline $\mathrm{K}^{+}$ & -0.05 & -0.08 & 0.14 & $0.50^{* *}$ & $0.79^{* *}$ & $0.39^{* *}$ & $0.81^{* * *}$ & 1 & & & & & & & \\
\hline $\mathrm{Mg}^{2+}$ & 0.13 & $0.33^{* *}$ & 0.03 & $0.47^{* *}$ & $0.46^{* *}$ & $0.71^{* *}$ & $0.37^{* *}$ & $0.32^{* *}$ & 1 & & & & & & \\
\hline $\mathrm{Ca}^{2+}$ & 0.00 & 0.15 & 0.02 & $0.34^{* *}$ & $0.72^{* *}$ & $0.60^{* *}$ & $0.52^{* *}$ & $0.65^{* *}$ & $0.50^{* *}$ & 1 & & & & & \\
\hline nss-SO ${ }_{4}{ }^{2-}$ & -0.16 & -0.11 & -0.01 & $0.55^{* *}$ & $0.99^{* *}$ & $0.58^{* *}$ & $0.74^{* * *}$ & $0.79^{* *}$ & $0.44^{* *}$ & $0.71^{* *}$ & 1 & & & & \\
\hline nss-Ca ${ }^{2+}$ & 0.00 & 0.10 & 0.03 & $0.32^{* *}$ & $0.69^{* *}$ & $0.53^{* *}$ & $0.53^{* *}$ & $0.65^{* *}$ & $0.45^{\text {** }}$ & $0.99^{* *}$ & $0.68^{* *}$ & 1 & & & \\
\hline nss- $\mathrm{K}^{+}$ & -0.05 & -0.12 & 0.14 & $0.49^{* *}$ & $0.77^{* *}$ & $0.34^{* *}$ & $0.82^{* *}$ & $0.99^{* *}$ & $0.28^{*}$ & $0.63^{* *}$ & $0.78^{* *}$ & $0.63^{* *}$ & 1 & & \\
\hline $\mathrm{OC}$ & -0.07 & -0.12 & 0.06 & $0.41^{* *}$ & $0.73^{* *}$ & $0.39^{* *}$ & $0.72^{* *}$ & $0.89^{* *}$ & $0.28^{*}$ & $0.59^{* *}$ & $0.73^{* * *}$ & $0.58^{* *}$ & $0.89^{* *}$ & 1 & \\
\hline $\mathrm{EC}$ & -0.04 & -0.15 & 0.10 & $0.46^{* *}$ & $0.77^{* *}$ & $0.36^{* *}$ & $0.78^{* * *}$ & $0.93^{* *}$ & $0.25^{*}$ & $0.58^{* *}$ & $0.78^{* *}$ & $0.58^{* *}$ & $0.93^{* *}$ & $0.93^{*}$ & 1 \\
\hline
\end{tabular}

t-test is $<0.01$ for the correlation where $r$ is $>0.70$.

Table 5. Summary of PAH concentrations in Phuket, Thailand.

\begin{tabular}{lllll}
\hline PAH $\left(\mathrm{ng} \mathrm{m}^{-3}\right)$ & Mean & SD & Min. & Max. \\
\hline Ace & 0.0140 & 0.0096 & 0.0015 & 0.0507 \\
Fl & 0.0112 & 0.0079 & 0.0082 & 0.0711 \\
Phe & 0.0409 & 0.0411 & 0.0261 & 0.0160 \\
Ant & 0.0067 & 0.0045 & 0.0059 & 0.0221 \\
Fluo & 0.0120 & 0.0120 & 0.0070 & 0.0160 \\
Pyr & 0.0110 & 0.0127 & 0.0062 & 0.0581 \\
B[a]A & 0.0340 & 0.0163 & 0.0206 & 0.0099 \\
Chry & 0.0067 & 0.0070 & 0.0028 & 0.0464 \\
B[b]F & 0.0239 & 0.0220 & 0.0228 & 0.0340 \\
B[k]F & 0.0238 & 0.0229 & 0.0086 & 0.0057 \\
B[a]F & 0.0032 & 0.0030 & 0.0025 & 0.0169 \\
B[e]P & 0.0144 & 0.0190 & 0.0056 & 0.0224 \\
B[a]P & 0.0174 & 0.0058 & 0.0072 & 0.0061 \\
Per & 0.0048 & 0.0500 & 0.0029 & 0.0652 \\
Ind & 0.0507 & 0.0590 & 0.0359 & 0.0709 \\
B[g,h,i]P & 0.0575 & 0.0118 & 0.0348 & 0.0032 \\
D[a,h]A & 0.0133 & 0.0208 & 0.0243 & 0.0356 \\
Cor & 0.0239 & 0.0091 & 0.0185 & 0.0129 \\
D[a,e]P & 0.0085 & 0.3480 & 0.0069 & - \\
EPAHs* & 0.3780 & - & . \\
\hline
\end{tabular}

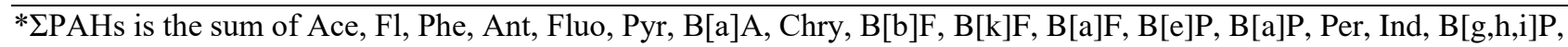
$\mathrm{D}[\mathrm{a}, \mathrm{h}] \mathrm{A}$, Cor, and D[a,e]P

\section{Principal Component Analysis (PCA)}

We used PCA to identify potential sources of the carbonaceous and WSIS compositions of the $\mathrm{PM}_{2.5}$ samples. The PCA method is a multivariate procedure that links multivariate data reduction by transforming the data into rectangular components. Hence, PCA reduces multidimensional data into smaller dimensions (Wold et al., 1987). In this section, source identification coupled with quantitative source apportionment of targeted chemical species is considered using PCA.

In this study, the concentrations of OC, EC, WSIS, and 19 individual PAHs from 75 samples were collected as active variables. The majority of the variance $(82.8 \%)$ of the scaled data was explained by five eigenvectors/principal components (PCs) (Table 6). The first PC (PC1) accounts for 55.5\% of the total variance, while the second PC (PC2) explains $10.9 \%$ of the total variance, followed by PC3-PC5 that describe $10.6 \%, 5.2 \%$, and $3.7 \%$ of the total variance, respectively.

In accounting for $55.5 \%$ of the total variance, $\mathrm{PC} 1$ showed high loading of $\mathrm{B}[\mathrm{g}, \mathrm{h}, \mathrm{i}] \mathrm{P}$, Cor, Ind, B[e]P, B[b]F, D[a,h]A, B[a]F, Pyr, B[a]P, B[k]F, Fluo, Chry, D[a,e]P, and Ant with corresponding correlation coefficients of $0.946,0.938$, 0.936, 0.893, 0.886, 0.874, 0.852, 0.850, 0.849, 0.835, 0.795, 0.7740 .761 , and 0.623 , respectively. Anthropogenic activity 
Table 6. Rotated component matrix ${ }^{\mathrm{a}}$ of carbonaceous compounds, WSIS, and 19 individual PAHs in the $\mathrm{PM}_{2.5} \mathrm{samples} \mathrm{from}$ Phuket, Thailand.

\begin{tabular}{|c|c|c|c|c|c|}
\hline \multirow{2}{*}{ Compositions } & \multicolumn{5}{|c|}{ Principal Component (PC) } \\
\hline & PC1 & PC2 & PC3 & PC4 & PC5 \\
\hline $\mathrm{TC}$ & 0.423 & 0.854 & 0.139 & 0.033 & -0.005 \\
\hline $\mathrm{OC}$ & 0.441 & 0.824 & 0.157 & 0.041 & -0.023 \\
\hline $\mathrm{EC}$ & 0.345 & 0.895 & 0.080 & 0.007 & 0.050 \\
\hline $\mathrm{F}^{-}$ & -0.225 & -0.002 & -0.038 & 0.052 & 0.618 \\
\hline $\mathrm{Cl}^{-}$ & -0.050 & -0.218 & -0.015 & 0.810 & 0.060 \\
\hline $\mathrm{NO}_{2}^{-}$ & 0.229 & -0.050 & -0.014 & -0.055 & 0.774 \\
\hline $\mathrm{NO}_{3}^{-}$ & 0.191 & 0.387 & 0.215 & 0.284 & 0.694 \\
\hline $\mathrm{SO}_{4}{ }^{2-}$ & 0.315 & 0.754 & 0.198 & 0.297 & -0.020 \\
\hline $\mathrm{Na}^{+}$ & 0.155 & 0.308 & 0.101 & 0.883 & -0.043 \\
\hline $\mathrm{NH}_{4}{ }^{+}$ & 0.312 & 0.734 & 0.265 & 0.022 & 0.345 \\
\hline $\mathrm{K}^{+}$ & 0.424 & 0.845 & 0.127 & 0.090 & 0.077 \\
\hline $\mathrm{Mg}^{2+}$ & -0.013 & 0.299 & 0.154 & 0.718 & 0.211 \\
\hline $\mathrm{Ca}^{2+}$ & 0.130 & 0.625 & 0.291 & 0.452 & -0.071 \\
\hline Ace & 0.259 & 0.092 & 0.838 & 0.053 & 0.011 \\
\hline $\mathrm{Fl}$ & 0.119 & 0.486 & 0.663 & 0.017 & 0.287 \\
\hline Phe & 0.408 & 0.478 & 0.614 & 0.075 & 0.212 \\
\hline Ant & 0.623 & 0.336 & 0.595 & 0.079 & 0.069 \\
\hline Fluo & 0.795 & 0.465 & 0.324 & 0.030 & 0.041 \\
\hline Pyr & 0.850 & 0.436 & 0.218 & 0.014 & 0.046 \\
\hline $\mathrm{B}[\mathrm{a}] \mathrm{A}$ & 0.257 & 0.187 & 0.780 & 0.178 & -0.127 \\
\hline Chry & 0.774 & 0.571 & 0.202 & 0.015 & 0.026 \\
\hline $\mathrm{B}[\mathrm{b}] \mathrm{F}$ & 0.886 & 0.322 & 0.171 & -0.013 & 0.014 \\
\hline $\mathrm{B}[\mathrm{k}] \mathrm{F}$ & 0.835 & 0.379 & 0.176 & 0.018 & -0.021 \\
\hline $\mathrm{B}[\mathrm{a}] \mathrm{F}$ & 0.852 & 0.290 & 0.233 & 0.007 & 0.114 \\
\hline $\mathrm{B}[\mathrm{e}] \mathrm{P}$ & 0.893 & 0.328 & 0.231 & 0.032 & 0.008 \\
\hline $\mathrm{B}[\mathrm{a}] \mathrm{P}$ & 0.849 & 0.399 & 0.244 & 0.061 & 0.015 \\
\hline Per & 0.373 & -0.021 & 0.069 & 0.000 & -0.208 \\
\hline Ind & 0.936 & 0.255 & 0.133 & 0.047 & -0.005 \\
\hline $\mathrm{B}[\mathrm{g}, \mathrm{h}, \mathrm{i}] \mathrm{P}$ & 0.946 & 0.200 & 0.149 & 0.050 & -0.005 \\
\hline $\mathrm{D}[\mathrm{a}, \mathrm{h}] \mathrm{A}$ & 0.874 & 0.109 & 0.069 & 0.057 & 0.031 \\
\hline Cor & 0.938 & 0.163 & 0.090 & 0.037 & 0.018 \\
\hline $\mathrm{D}[\mathrm{a}, \mathrm{e}] \mathrm{P}$ & 0.761 & 0.095 & 0.045 & 0.099 & -0.046 \\
\hline Variance [\%] & 55.5 & 10.9 & 6.1 & 5.2 & 5.1 \\
\hline Estimated source & Vehicular & Biomass & Diesel & Sea Salt & Industrial \\
\hline & Exhausts & Burning & Emissions & Aerosols & Emissions \\
\hline
\end{tabular}

${ }^{a}$ Rotation Method: Varimax with Kaiser Normalization.

Bold: loading $>0.5$

is concentrated in urban areas; therefore, these positive loadings in PC1 could be attributed to anthropogenic activities involving combustion of coal, diesel, and petroleum. In particular, the high levels of molecular 4-6 ring PAHs found in PC1 could be related to vehicular exhausts (Miguel and Pereira, 1989; Harrison et al., 1996) and/or gasoline vehicles (Schauer et al., 2002, Teixeira et al., 2013).

Significant correlations of EC, TC, $\mathrm{K}^{+}, \mathrm{OC}, \mathrm{SO}_{4}{ }^{2-}, \mathrm{NH}_{4}^{+}$, $\mathrm{Ca}^{2+}$, and Chry were found in $\mathrm{PC} 2$ with correlation coefficients of $0.895,0.854,0.845,0.824,0.754,0.734,0.625$, and 0.571 , respectively, accounting for $10.9 \%$ of the total variance. This PC is believed to be the biomass burning source of carbonaceous compositions. Due to $\mathrm{OC}, \mathrm{EC}$ and $\mathrm{K}^{+}$are generated from biomass burning, $\mathrm{BB}$ emissions contain a significant amount of WSIS, such as $\mathrm{NH}_{4}^{+}$and $\mathrm{K}^{+}$(Lee et al., 2016; Pani et al., 2018). Moreover, OC and EC can be related to biomass burning as well (Mkoma et al., 2013).

As illustrated in Table 6, PC3 represented $6.1 \%$ of the total variance. Several studies reported that Phe and Ant could be used as geochemical tracers of PM released from diesel engine exhausts and coal combustion (Fang et al., 2006). Findings of a previous study that analysed air samples collected at Singapore suggested that PAH congeners with two and three rings were higher in concentration while the levels of the PAHs of higher molecular weight, four to six rings, are less. The difference in the concentration trends may be a result of the distinctive depletion rates of individual PAHs related differences in fuel characteristics (See. et al., 2006). In this study, Phe exhibited the highest atmospheric concentrations with an average value of $0.041 \pm 0.041 \mu \mathrm{g} \mathrm{m}^{-3}$.

PC4 represented $5.2 \%$ of the total variance. The comparatively high loadings of $\mathrm{Na}^{+}(r=0.883), \mathrm{Cl}^{-}(r=$ 
$0.810)$, and $\mathrm{Mg}^{2+}(r=0.718)$ underline the importance of marine aerosols, which explanation is in good compliance with previous studies conducted in Auckland and Brisbane, underlined that $\mathrm{Cl}^{-}$as a chemical tracer of maritime aerosols (Chan et al., 1997; Wang et al., 2005).

PC5 represented $5.1 \%$ of the total variance, with a high loading factor for $\mathrm{NO}_{2}^{-}, \mathrm{NO}_{3}{ }^{-}$and $\mathrm{F}^{-}$. Over recent decades, numerous studies have underlined the importance of industrial activities as one of the major sources of particulate $\mathrm{F}^{-}$in the urban atmosphere (Lovelock, 1971; Haidouti et al., 1993; Mukherjee et al., 2003). For instance, hydrofluoric acid is used widely in the manufacture of chemicals and plastics and in laundries (WHO, 2000). The relatively low percentage contribution of industrial emissions was found in reasonable accord with the fact that the factories in Phuket account for only $0.31 \%$ of total number of factories in Thailand, based on a statistical survey conducted by the Department of Industrial Works of the Ministry of Industry in 2019. Consequently, it appears plausible that "industrial emissions" represented by PC5 account for only 5.1\% of the total variance.

\section{CONCLUSIONS}

This study investigated the carbonaceous aerosol compositions (OC, EC, WSIS, and PAHs) of $\mathrm{PM}_{2.5}$ samples obtained in Phuket. The average $\mathrm{PM}_{2.5}$ concentration was 1.7 times higher than the USEPA standard. The application of diagnostic binary ratios of OC/EC and estimations of secondary organic carbon (SOC) in this study highlighted that the enhanced impacts of incomplete combustion emissions, such as motor vehicle exhaust, fuel burning, and biomass burning. Strong correlation $(r=0.80)$ was found between nss- $\mathrm{K}^{+}$and OC, which was also shown to be affected significantly by long-range atmospheric transport of organic aerosols associated with BB. In this study, the concentration of individual PAHs relatively high abundances of $\mathrm{B}[\mathrm{g}, \mathrm{h}, \mathrm{i}] \mathrm{P}$ and Ind were detected, indicating that motor vehicles, petroleum/oil combustion, and industrial waste burning are emission sources of the PAHs found in the ambient air of Phuket.

Source identification of the chemical species by PCA revealed that five sources of carbonaceous composition observed in the $\mathrm{PM}_{2.5}$ samples explained $82.8 \%$ of the total variance. The highlight showed that vehicular exhausts, BB, diesel emissions, sea salt aerosols, and industrial emissions accounted for $55.5 \%, 10.9 \%, 6.1 \%, 5.20 \%$, and $5.1 \%$ of the total variance, respectively. Interestingly, the PCA result showed vehicular exhausts as the main source. However, the contributions of both marine aerosols and BB to SOC also played a major role. Overall, $17.2 \%$ of the variance could not be attributed to the five primary local and/or regional sources; this proportion was considered to originate from other combustion activities such as incinerators, incense burning, and cooking.

\section{ACKNOWLEDGEMENTS}

This study was performed with the approval of the
Thailand Research Fund (TRF) and Institute of Earth Environment, Chinese Academy of Science (IEECAS). The authors acknowledge the assistance of local staff from the Prince of Songkla University (Phuket campus) in the field sampling.

\section{REFERENCE}

Achten, C. and Andersson, J.T. (2015). Overview of polycyclic aromatic compounds (PAC). Polycyclic Aromat. Compd. 35: 177-186. https://doi.org/10.1080/10 406638.2014.994071

Al-Mulali, U., Ozturk, I., and Lean, H.H. (2015). The influence of economic growth, urbanization, trade openness, financial development, and renewable energy on pollution in Europe. Nat. Hazards 79: 621-644. https://doi.org/10.1007/s11069-015-1865-9

Bakirtas, T. and Akpolat, A.G. (2018). The relationship between energy consumption, urbanization, and economic growth in new emerging-market countries. Energy 147: 110-121. https://doi.org/10.1016/j.energy.2018.01.011

Behrooz, R.D., Esmaili-Sari, A., Bahramifar, N., Kaskaoutis, D.G., Saeb, K. and Rajaei, F. (2017). Trace-element concentrations and water-soluble ions in size-segregated dust-borne and soil samples in Sistan, southeast Iran. Aeolian Res. 25: 87-105. https://doi.org/10.1016/j.aeolia. 2017.04.001

Bocchi, C., Bazzini, C., Fontana, F., Pinto, G. and Cassoni, F. (2017). Genotoxicity of airborne $\mathrm{PM}_{2.5}$ assessed by salmonella and comet assays in five cities of the EmiliaRomagna (Italy) mutagenicity monitoring network. Environ. Mol. Mutagen. 58: 719-729. https://doi.org/10. 1002/em.22141

Cao, J.J., Lee, S.C., Ho, K.F., Zhang, X.Y., Zou, S.C., Fung, K., Chow, J.C. and Watson, J.G. (2003). Characteristics of carbonaceous aerosol in pearl river Delta region, China during 2001 winter period. Atmos. Environ. 37: 14511460. https://doi.org/10.1016/S1352-2310(02)01002-6

Cao, J.J., Wu, F., Chow, J.C., Lee, S.C., Li, Y., Chen, S.W., An, Z.S., Fung, K.K., Watson, J. G., Zhu, C.S. and Liu, S.X. (2005). Characterization and source apportionment of atmospheric organic and elemental carbon during fall and winter of 2003 in Xi'an, China. Atmos. Chem. Phys. 5: 3127-3137. https://doi.org/10.5194/acp-5-3127-2005

Castro, L.M., Pio, C.A., Harrison, R.M. and Smith, D.J.T., (1999). Carbonaceous aerosol in urban and rural European atmospheres: Estimation of secondary organic carbon concentrations. Atmos. Environ. 33: 2771-2781. https://doi.org/10.1016/S1352-2310(98)00331-8

Chaiyo, U., Savitri, G. and Wanthongchai, K. (2011). Carbon storage in above-ground biomass of tropical deciduous forest in Ratchaburi Province, Thailand. World Acad. Sci. Eng. Technol. 58: 636-641. https://doi.org/10. 5281/zenodo.1058691

Chaiyo, U., Pizzo, Y. and Garivait, S. (2013). Estimation of carbon released from dry dipterocarp forest fires in Thailand. Int. J. Environ. Sci. 7: 522-525. https://doi.org/ 10.5281/zenodo. 1087748

Chaiyo, U. and Garivait, S. (2014). Estimation of black 
carbon emissions from dry dipterocarp forest fires in Thailand. Atmosphere 5: 1002-1019. https://doi.org/10.33 90/atmos5041002

Chen, J., Li, C., Ristovski, Z., Milic, A., Gu, Y., Islam, M.S., Wang, S., Hao, J., Zhang, H., He, C., Guo, H., Fu, H., Miljevic, B., Morawska, L., Thai, P., Lam, Y.F., Pereira, G., Ding, A., Huang, X. and Dumka, U.C. (2017). A review of biomass burning: Emissions and impacts on air quality, health and climate in China. Sci. Total Environ. 579: 1000-1034. https://doi.org/10.1016/j.scitotenv.2016. 11.025

Chen, J., Augenbroe, G., Zeng, Z. and Song, X. (2020). Regional difference and related cooling electricity savings of air pollutant affected natural ventilation in commercial buildings across the US. Build. Sci. 172: 106700. https://doi.org/10.1016/j.buildenv.2020.106700

Cheng, Y., Lee, S., Gu, Z., Ho, K., Zhang, Y., Huang, Y., Chow, J.C., Watson, J.G., Cao, J. and Zhang, R. (2015). $\mathrm{PM}_{2.5}$ and $\mathrm{PM}_{10-2.5}$ chemical composition and source apportionment near a Hong Kong roadway. Particuology 18: 96-104. https://doi.org/10.1016/j.partic.2013.10.003

ChooChuay, C., Pongpiachan, S., Tipmanee, D., Deelaman, W., Iadtem, N., Suttinun, O., Wang, Q., Xing, L., Li, G., Han, Y., Hashmi, M. Z., Palakun, J., Poshyachinda, S., Aukkaravittayapun, S., Surapipith, V. and Cao, J. (2020). Effects of agricultural waste burning on $\mathrm{PM}_{2.5}$-bound polycyclic aromatic hydrocarbons, carbonaceous compositions, and water-soluble ionic species in the ambient air of Chiang-Mai, Thailand. Polycyclic Aromat. Compd. https://doi.org/10.1080/10406638.2020.1750436

Chow, J.C., Watson, J.G., Pritchett, L.C., Pierson, W.R., Frazier, C.A. and Purcell, R.G. (1993). The dri thermal/optical reflectance carbon analysis system: Description, evaluation and applications in U.S. Air quality studies. Atmos. Environ. 27: 1185-1201. https://doi.org/ 10.1016/0960-1686(93)90245-T

Chow, J.C., Watson, J.G., Kuhns, H., Etyemezian, V., Lowenthal, D.H., Crow, D., Kohl, S.D., Engelbrecht, J.P. and Green, M.K. (2004). Source profiles for industrial, mobile and area sources in the big bend regional aerosol visibility and observational (BRAVO) study. Chemosphere 54: 185-208. https://doi.org/10.1016/j.chemosphere.200 3.07.004

Chow, J.C., Watson, J.G., Chen, L.W.A., Chang, M.C.O., Robinson, N.F., Trimble, D. and Kohl, S. (2007). The IMPROVE_A temperature protocol for thermal/optical carbon analysis: Maintaining consistency with a long term database. J. Air Waste Manage. Assoc. 57: 10141023. https://doi.org/10.3155/1047-3289.57.9.1014

Chuang, M.T., Chou, C.K., Sopajareepom, K., Lin, N.H., Wang, J.L., Sheu, G.R., Chang, Y.C. and Lee, C.T. (2013). Characterization of aerosol chemical properties from near-source biomass burning in Chiang Mai, Thailand during 7-SEAS/Dongsha experiment. Atmos. Environ. 78: 72-81. https://doi.org/10.1016/j.atmosenv. 2012.06.056

Cohen, A.J., Brauer, M., Burnett, R., Anderson, H.R., Frostad, J., Estep, K., Balakrishnan, K., Brunekreef, B., Dandona, L., Dandona, R., Feigin, V., Freedman, G.,
Hubbell, B., Jobling, A., Kan, H., Knibbs, L., Liu, Y., Martin, R., Morawska, L., ... Forouzanfar, M.H. (2017). (2017). Estimates and 25-year trends of the global burden of disease attributable to ambient air pollution: an analysis of data from the Global Burden of Diseases Study 2015. Lancet 389: 1907-1918. https://doi.org/10.1016/S01406736(17)30505-6

Cuccia, E., Massabò, D., Ariola, V., Bove, M.C., Fermo, P., Piazzalunga, A. and Prati, P. (2013). Sizeresolved comprehensive characterization of airborne particulate matter. Atmos. Environ. 67: 14-26. https://doi.org/10.101 6/j.atmosenv.2012.10.045

Dachs, J. and Eisenreich, S.J. (2000). Adsorption onto aerosol soot carbon dominates gas-particle partitioning of polycyclic aromatic hydrocarbons. Environ. Sci. Technol. 34: 3690-3697. https://doi.org/10.1021/es991201+

Dahari, N., Muda, K., Latif, M.T. and Hussein, N. (2019). Studies of atmospheric $\mathrm{PM}_{2.5}$ and its inorganic water soluble ions and trace elements around southeast Asia: A Review. Asia-Pac. J. Atmos. Sci. https://doi.org/10.1007/ s13143-019-00132-X

Dao, X., Wang, Z., Lv, Y., Teng, E., Zhang, L. and Wang, C. (2014). Chemical characteristics of water-soluble ions in particulate matter in three metropolitan areas in the North China Plain. PLoS One 9: e113831. https://doi.org/10.1371/journal.pone.0113831

Deng, X.L., Shi, C.E., Wu, B.W., Yang, Y.J., Jin, Q., Wang, H.L., Zhu, S. and Yu, C. (2016). Characteristics of the water-soluble components of aerosol particles in Hefei, China. J. Environ. Sci. 42: 32-40. https://doi.org/10.1016 /j.jes.2015.07.010

Doiron, D., Hoogh, K. de, Probst-Hensch, N., Fortier, I., Cai, Y., Matteis, S.D. and Hansell, A.L. (2019). Air pollution, lung function and COPD: Results from the population-based UK Biobank study. Eur. Respir. J. 54: 1802140. https://doi.org/10.1183/13993003.02140-2018

Duangkaew, S., Limpaseni, W. and Suwattiga, P. (2013). Carbon composition of $\mathrm{PM}_{10}$ and $\mathrm{PM}_{2.5}$ in Bangkok ambient air from a city center sampling site. Rangsit $J$. Arts Sci. 3: 17-23. https://doi.org/10.14456/rjas.2012.18

Dumka, U.C., Kaskaoutis, D.G., Sagar, R., Chen, J., Singh, N. and Tiwari, S. (2017). First results from light scattering enhancement factor over central Indian Himalaya during GVAX campaign. Sci. Total Environ. 605-606: 124-138. https://doi.org/10.1016/j.scitotenv.2017.06.138

Dung, N.T. (1996). Determination of some selected Polycyclic Aromatic Hydrocarbons on particulates emitted from the thermal power plant of the Bai Bang paper company, Vietnam. Master's Thesis. Division of Environmental Engineering. Asian Institute of Technology.

Fang, G.C., Wu, Y.S., Chen, J.C., Chang, C.N. and Ho, T.T. (2006). Characteristic of polycyclic aromatic hydrocarbon concentrations and source identification for fine and coarse particulates at Taichung Harbor near Taiwan Strait during 2004-2005. Sci. Total Environ. 366: 729-738. https://doi.org/10.1016/j.scitotenv.2005.09.075

Fung, K., Chow, J.C. and Watson, J.G. (2002). Evaluation of $\mathrm{OC} / \mathrm{EC}$ speciation by thermal manganese dioxide oxidation and the IMPROVE method. J. Air Waste Manage. 
Assoc. 52: 1333-1341. https://doi.org/10.1080/10473289. 2002.10470867

Gelencsér, A. (2004). Carbonaceous aerosols. Springer, Netherlands.

George, K.S., Nair, P.R., Parameswaran, K., Jacob, S. and Abraham, A. (2008). Seasonal trend in chemical composition of aerosols at a tropical coastal site of India. J. Geophys. Res. 113: D16209. https://doi.org/10.1029/20 07JD009507

Gocht, T., Moldenhauer, K.M. and Püttmann, W. (2001). Historical record of polycyclic aromatic hydrocarbons (PAHs) and heavy metals in floodplain sediments from the Rhine River (Hessisches Ried, Germany). Appl. Geochem. 16: 1707-17821. https://doi.org/10.1016/S08 83-2927(01)00063-4

Haidouti, C., Chronopoulou, A. and Chronopoulos, J. (1993). Effects of fluoride emissions from industry on the fluoride concentration of soils and vegetation. Biochem. Syst. Ecol. 21: 195-208. https://doi.org/10.1016/03051978(93)90037-R

Han, Y.M., Cao, J.J., Chow, J.C., Watson, J.G., Fung, K., Jin, Z.D., Liu, S.X. and An, Z.S. (2007). Evaluation of the thermal/optical reflectance method for discrimination between soot- and char-EC. Chemosphere 69: 569-574. https://doi.org/10.1016/j.chemosphere.2007.03.024

Han, Y.M., Cao, J.J., Chow, J.C., Watson, J.G., An, Z.S. and Liu, S.X. (2009). Elemental carbon in urban soils and road dusts in Xi'an, China and its implication for air pollution. Atmos. Environ. 43: 2464-2470. https://doi.org/10.1016/ j.atmosenv.2009.01.040

Harrison, R.M., Smith, D.J.T. and Luhana, L. (1996). Source apportionment of atmospheric polycyclic aromatic hydrocarbons collected from an urban location in Birmingham, UK. Environ. Sci. Technol. 30: 825-832. https://doi.org/10.1021/es950252d

Heald, C.L., Henze, D.K., Horowitz, L.W., Feddema, J., Lamarque, J.F., Guenther, A., Hess, P.G., Vitt, F., Seinfeld, J.H., Goldstein, A.H. and Fung, I. (2008). Predicted change in global secondary aerosol concentrations in response to future climate, emissions and land use change. J. Geophys. Res. 113: D05211. https://doi.org/10.1029/2 007JD009092

Hegde, P., Sudheer, A.K., Sarin, M.M. and Manjunatha, B.R. (2007). Chemical characteristics of atmospheric aerosols over southwest coast of India. Atmos. Environ. 41: 77517766. https://doi.org/10.1016/j.atmosenv.2007.06.062

Ho, S.S. and Yu, J.Z. (2004). In-injection port thermal desorption and subsequent gas chromatography-mass spectrometric analysis of polycyclic aromatic hydrocarbons and n-alkanes in atmospheric aerosol samples. $J$. Chromatogr. A 1059: 121-129. https://doi.org/10.1016/j. chroma.2004.10.013

Huang, T., Chen, J., Zhao, W., Cheng, J. and Cheng, S. (2016). Seasonal variations and correlation analysis of water-soluble inorganic ions in $\mathrm{PM}_{2.5}$ in Wuhan, 2013. Atmosphere 7: 49. https://doi.org/10.3390/atmos7040049

Idowu, O., Semple, K.T., Ramadass, K., O'Connor, W., Hansbro, P. and Thavamani P. (2019). Beyond the obvious: Environmental health implications of polar polycyclic aromatic hydrocarbons. Environ. Int. 123: 543-557. https://doi.org/10.1016/j.envint.2018.12.051

Janta, R. and Chantara, S. (2017). Tree bark as bioindicator of metal accumulation from road traffic and air quality map: A case study of Chiang Mai, Thailand. Atmos. Pollut. Res. 8: 956-967. https://doi.org/10.1016/j.apr.201 7.03.010

Javid, M., Bahramifar, N., Younesi, H., Taghavi, S.M. amd Givehchi, R. (2015). Dry deposition, seasonal variation and source interpretation of ionic species at Abali, Firouzkouh and Varamin, Tehran province, Iran. Atmos. Res. 157: 74-90. https://doi.org/10.1016/j.atmosres.2015. 01.018

Jiménez-Moreno, G., Fauquette, S. and Suc, J.P. (2008). Vegetation, climate and paleoaltitude reconstructions of eastern alpine mountain ranges during the Miocene based on pollen records from Austria: Central Europe. $J$. Biogeogr. 35: 1638-1649. https://doi.org/10.1111/j.13652699.2008.01911.x

Jinsart, W., Tamura, K., Loetkamonwit, S., Sarawut Thepanondh, S., Kanae, K. and Yano, E. (2002). Roadside particulate air pollution in Bangkok. J. Air Waste Manage. Assoc. 52: 1102-1110. https://doi.org/10.1080/10473289. 2002.10470845

Jones, K.C. and de Voogt, P. (1999). Persistent organic pollutants (POPs): State of the science. Environ. Pollut. 100: 209-221. https://doi.org/10.1016/S0269-7491(99)0 0098-6

Kalita, G., Kunchala, RK., Fadnavis, S. and Kaskaoutis, D.G. (2020). Long term variability of carbonaceous aerosols over Southeast Asia via reanalysis: Association with changes in vegetation cover and biomass burning. Atmos. Res. 245: 105064. https://doi.org/10.1016/j.atmos res.2020.105064

Karthikeyan, S. and Balasubramanian, R. (2006). Determination of water-soluble inorganic and organic species in atmospheric fine particulate matter. Microchem. $J$. 82: 49-55. https://doi.org/10.1016/j.microc.2005.07.003

Kaskaoutis, D.G., Grivas, G., Theodosi, C., Tsagkaraki, M., Paraskevopoulou, D., Stavroulas, I., Liakakou, E., Gkikas, A., Hatzianastassiou, N., Wu, C., Gerasopoulos, E. and Mihalopoulos. N. (2020). Carbonaceous aerosols in contrasting atmospheric environments in Greek cities: Evaluation of the EC-tracer methods for secondary organic carbon estimation. Atmosphere 11: 161. https://doi. org/10.3390/atmos11020161

Keene, W.C., Pszenny, A.A.P., Galloway, J.N. and Hawley, M.E. (1986). Sea-salt corrections and interpretation of constituent ratios in marine precipitation. J. Geophys. Res. 91: 6647-6657. https://doi.org/10.1029/JD091iD06 p06647

Kocaka, M., Mihalopoulosb, N. and Kubilay, N. (2007). Chemical composition of the fine and coarse fraction of aerosols in the northeastern Mediterranean. Atmos. Environ. 41: 7351-7368. https://doi.org/10.1016/j.atmose nv.2007.05.011

Kundu, S., Kawamura, K. and Lee, M. (2010). Seasonal variations of diacids, ketoacids, and $\alpha$-dicarbonyls in aerosols at Gosan, Jeju Island, South Korea: Implications 
for sources, formation, and degradation during long-range transport. J. Geophys. Res. 115: D19307. https://doi.org/ 10.1029/2010JD013973

Kunwar, B. and Kawamura, K. (2014). One-year observations of carbonaceous and nitrogenous components and major ions in the aerosols from subtropical Okinawa Island, an outflow region of Asian dusts. Atmos. Chem. Phys. 14: 1819-1836. https://doi.org/10.5194/acp-14-18192014

Lai, S., Zou, S., Cao, J., Lee, S. and Ho, K. (2007). Characterizing ionic species in $\mathrm{PM}_{2.5}$ and $\mathrm{PM}_{10}$ in four Pearl River Delta cities, South China. J Environ Sci. 19: 939-947. https://doi.org/10.1016/S1001-0742(07)60155-7

Lawal, A.T. (2017). Polycyclic aromatic hydrocarbons. A review. Cogent Environ. Sci. 3: 1339841. https://doi.org/ 10.1080/23311843.2017.1339841

Lee, C., Ram, S.S., Nguyen, D., Chou, C., Chang, S., Lin, N., Chang, S., Hsiao, T., Sheu, G., OuYang, C., Chi, K., Wang, S. and Wu, X. (2016). Aerosol chemical profile of near-source biomass burning smoke in Sonla, Vietnam during 7- SEAS campaigns in 2012 and 2013. Aerosol Air Qual. Res. 16: 2603-2617. https://doi.org/10.4209/aaqr. 2015.07.0465

Lelieveld, J., Klingmuller, K., Pozzer, A., Poschl, U., Fnais, M., Daiber, A. and Munzel, T. (2019). Cardiovascular disease burden from ambient air pollution in Europe reassessed using novel hazard ratio functions. Eur. Heart $J$. 40: 1590-1596. https://doi.org/10.1093/eurheartj/ehz135

Li, W., Bai, Z., Liu, A., Chen, J. and Chen, L. (2009). Characteristics of major $\mathrm{PM}_{2.5}$ components during winter in Tianjin, China. Aerosol Air Qual. Res. 9: 105-119. https://doi.org/10.4209/aaqr.2008.11.0054

Li, X., Wang, L., Wang, Y., Wen, T., Yang, Y., Zhao, Y. and Wang, Y. (2012). Chemical composition and size distribution of airborne particulate matters in Beijing during the 2008 Olympics. Atmos. Environ. 50: 278-286. https://doi.org/10.1016/j.atmosenv.2011.12.021

Lin, J.J. and Tai, S.H. (2001). Concentrations and distributions of carbonaceous species in ambient particles in Kaohsiung City, Taiwan. Atmos. Environ. 35: $2627-$ 2636. https://doi.org/10.1016/S1352-2310(00)00444-1

Lin, Y.C., Li, Y.C., Shangdiar, S., Chou, F.C., Sheu, Y.T. and Cheng, P.P. (2019). Assessment of $\mathrm{PM}_{2.5}$ and PAH content in $\mathrm{PM}_{2.5}$ emitted from mobile source gasolinefueled vehicles in concomitant with the vehicle model and mileages. Chemosphere 226: 502-508. https://doi.org/10. 1016/j.chemosphere.2019.03.137

Liu, J., Zhang, X.L., Xu, X.F. and Xu, H.H. (2011). Comparison analysis of variation characteristics of $\mathrm{SO}_{2}$, $\mathrm{NO}_{\mathrm{x}}, \mathrm{O}_{3}$ and $\mathrm{PM}_{2.5}$ between rural and urban areas, Beijing. Huanjing Kexue 29: 1059-1065.

Lovelock, J.E. (1971). Air pollution and climatic change. Atmos. Environ. 5: 403-411 https://doi.org/10.1016/000 4-6981(71)90143-0

Manoli, E., Kouras, A. and Samara, C. (2004). Profile analysis of ambient and source emitted particle-bound polycyclic aromatic hydrocarbons from three sites in Northern Greece. Chemosphere 56: 867-878. https://doi. org/10.1016/j.chemosphere.2004.03.013
Matsumoto, K., Nagao, I., Tanaka, H., Miyaji, H., Iida, T. and Ikebe, Y. (1998). Seasonal characteristics of organic and inorganic species and their size distributions in atmospheric aerosols over the Northwest Pacific Ocean. Atmos. Environ. 32: 1931-1946. https://doi.org/10.1016/ S1352-2310(97)00499-8

Mauderly, J.L. and Chow, J.C. (2008). Health effects of organic aerosols. Inhalation Toxicol. 20: 257-288. https://doi.org/10.1080/08958370701866008

Miguel, A.H. and Pereira, P.A.P. (1989). Benzo(k)fuoranthene, benzo(ghi)perylene, and indeno (1,2,3,-cd)pyrene: New tracers of automotive emissions in receptor modeling. Aerosol. Sci. Technol. 10: 292-295. https://doi.org/10.1080/02786828908959265

Mkoma, S.L., Kawamura, K. and Fu, P.Q. (2013). Contributions of biomass/biofuel burning to organic aerosols and particulate matter in Tanzania, East Africa, based on analysis of ionic species, organic and elemental carbon, levoglucosan and mannosan. Atmos. Chem. Phys. 13: 10325-30338. https://doi.org/10.5194/acp-13-103252013

Mkoma, S.L., Rocha, G.O., Regis, A.C.D., Domingos, J.S.S., Santos, J.V.S., Andrade, S.J., Carvalho, L.S. and Andrade, J.B. (2014). Major ions in $\mathrm{PM}_{2.5}$ and $\mathrm{PM}_{10}$ released from buses: The use of diesel/biodiesel fuels under real conditions. Fuel. 115: 109-117. https://doi.org/ 10.1016/j.fuel.2013.06.044

Mukherjee, S.C., Rahman, M.M., Chowdhury, U.K., Sengupta, M.K., Lodh, D., Chanda, C.R., Saha, K.C. and Chakraborti, D. (2003). Neuropathy in arsenic toxicity from groundwater arsenic contamination in West Bengal, India. J. Environ. Sci. Health., Part A 38: 165-183. https://doi.org/10.1081/ESE-120016887

Na, K., Sawant, A.A., Song, C. and Cocker, R.D. (2004). Primary and secondary carbonaceous species in the atmosphere of Western Riverside County, California. Atmos. Environ. 38: 1345-1355. https://doi.org/10.1016/ j.atmosenv.2003.11.023

Nhung, N.T.T., Schindler, C., Chau, N.Q., Hanh, P.T., Hoang, L.T., Dien, T.M., Thanh, N.T.N. and Künzli, N. (2019). Exposure to air pollution and risk of hospitalization for cardiovascular diseases amongst Vietnamese adults: Case-crossover study. Sci. Total Environ. 703: 134637. https://doi.org/10.1016/j.scitotenv.2019.134637

Pani, S.K., Lin, N.H., Chantara, S., Wang, S.H., Khamkaew, C., Prapamontol, T. and Janjai, S. (2018). Radiative response of biomass-burning aerosols over an urban atmosphere in northern peninsular Southeast Asia. Sci. Total Environ. 633: 892-911. https://doi.org/10.1016/j.s citotenv.2018.03.204

Park, S.M., Seo, B.K., Lee, G., Kahng, S.H. and Jang, Y.W. (2015). Chemical composition of water soluble inorganic species in precipitation at Shihwa Basin, Korea. Atmosphere 6: 732-750. https://doi.org/10.3390/atmos6060732

Park, S.S. and Cho, Y.S. (2011). Tracking sources and behaviors of water-soluble organic carbon in fine particulate matter measured at an urban site in Korea. Atmos. Environ. 45: 60-72. https://doi.org/10.1016/j.atm osenv.2010.09.045 
Phairuang, W., Inerba, M., Furuuchia, M., Hata, M., Tekasakuld, S. and Tekasakul, P. (2020). Sizefractionated carbonaceous aerosols down to $\mathrm{PM}_{0.1}$ in southern Thailand: Local and long-range transport effects. Environ. Pollut. 260: 114031. https://doi.org/10.1 016/j.envpol.2020.114031

Pongpiachan, S., Thamanu, K., Ho., S, Lee, C. and Sompongchaiyakul, P. (2009). Predictions of gas-particle partitioning coefficients $(\mathrm{Kp})$ of polycyclic aromatic hydrocarbons at various occupational environments of Songkhla province, Thailand. Southeast Asian. Southeast Asian J. Trop. Med. Public Health 40: 1377-1394. https://www.tm.mahidol.ac.th/seameo/2009-40-6/284592.pdf

Pongpiachan, S. (2013). Vertical distribution and potential risk of particulate polycyclic aromatic hydrocarbons in high buildings of Bangkok, Thailand. Asian Pac. J. Cancer Prev. 14: 1865-1877. https://doi.org/10.7314/apj cp.2013.14.3.1865

Pongpiachan, S, Ho, K.F. and Cao, J. (2013). Estimation of gas-particle partitioning coefficients $(\mathrm{Kp})$ of carcinogenic polycyclic aromatic hydrocarbons in carbonaceous aerosols collected at Chiang-Mai, Bangkok and Hat-Yai, Thailand. Asian Pac. J. Cancer Prev. 14: 3369-3384. https://doi.org/10.7314/apjcp.2013.14.4.2461

Pongpiachan, S., Ho, K.F. and Cao, J. (2014a). Effects of biomass and agricultural waste burnings on diurnal variation and vertical distribution of OC/EC in Hat-Yai City, Thailand. Asian J. Appl. Sci. 7: 360-374. https://doi.org/10.3923/ajaps.2014.360.374

Pongpiachan, S., Kudo, S. and Sekiguchi, K. (2014b). Chemical characterization of carbonaceous $\mathrm{PM}_{10}$ in Bangkok, Thailand. Asian J. Appl. Sci. 7: 325-342. https://doi.org/10.3923/ajaps.2014.325.342

Pongpiachan, S., Tipmanee, D., Khumsup, C., Kittikoon, I., and Hirunyatrakul, P. (2015). Assessing risks to adults and preschool children posed by $\mathrm{PM}_{2.5}$-bound polycyclic aromatic hydrocarbons (PAHs) during a biomass burning episode in Northern Thailand. Sci. Total Environ. 508: 435-444. https://doi.org/10.1016/j.scitotenv.2014.12.019

Pongpiachan, S., Hattayanone, M. and Cao, J. (2017). Effect of agricultural waste burning season on $\mathrm{PM}_{2.5}$-bound polycyclic aromatic hydrocarbon (PAH) levels in Northern Thailand. Atmos. Pollut. Res. 8: 1069-1080. https://doi.org/10.1016/j.apr.2017.04.009

Putaud, J.P., Van, Dingenen, R., Alastuey, Bauer, H., Birmili, W. and Cyrys, J. (2010). A European aerosol phenomenology -3: Physical and chemical characteristics of particulate matter from 60 rural, urban, and kerbside sites across Europe. Atmos. Environ. 44: 1308-1320. https://doi.org/10.1016/j.atmosenv.2009.12.011

Ravindra, K., Sokhi, R. and Grieken, R. (2008). Atmospheric polycyclic aromatic hydrocarbons: Source attribution, emission factors and regulation. Atmos. Environ. 42: 28952921. https://doi.org/10.1016/j.atmosenv.2007.12.010

Salma, I., Zsigrai, A.V., Machon, A., Varga, T., Major, I., Gergely, V. and Molnár, M. (2020). Fossil fuel combustion, biomass burning and biogenic sources of fine carbonaceous aerosol in the Carpathian Basin. Atmos.
Chem. Phys. 20: 4295-4312. https://doi.org/10.5194/acp20-4295-2020

Schauer, J.J., Kleeman, M.J., Cass, G.R. and Simoneit, B.R.T. (2002). Measurement of emissions from air pollution sources. 5. $\mathrm{C}_{1}-\mathrm{C}_{32}$ organic compounds from gasoline-powered motor vehicles. Environ. Sci. Technol. 36: 1169-1180. https://doi.org/10.1021/es0108077

Schummer, C., Mothiron, E., Appenzeller, R.M.B., Wennig, R. and Millet, M. (2010). Gas/particle partitioning of currently used pesticides in the atmosphere of Strasbourg (France). Air Qual. Atmos. Health 3: 171-181. https://doi.org/10.1007/s11869-010-0065-8

See, S.W., Balasubramanian, R., Yang, T.S. and Karthikeyan, S. (2006). Assessing exposure to diesel exhaust particles: A case study. J. Toxicol. Environ. Health Part A 69: 1909-1925. https://doi.org/10.1080/15 287390600751280

Seinfeld, J.H. and Pandis, S.N. (2006). Atmospheric chemistry and physics: From air pollution to climate change. John Wiley \& Sons Inc., New York.

Shih, T.S., Lai, C.H., Hung, H.F., Ku, S.Y., Tsai, P.J., Yang, T., Liou, S.H., Loh, C.H. and Jaakkola, J.J.K. (2008). Elemental and organic carbon exposure in highway tollbooths: A study of Taiwanese toll station workers. Sci. Total Environ. 402: 163-170. https://doi.org/10.1016/j.s citotenv.2008.04.051

Silva, M.A.B. (2005). Sistema de classificacão Fuzzy para áreas contaminadas. $\mathrm{PhD}$ thesis, Federal University of Rio de Janeiro, Brazil, pp. 11-13.

Smith, D.J.T. and Harrison, R.M. (1998). Polycyclic aromatic hydrocarbons in atmospheric particles. In Atmospheric particles, Harrison, R.M. and Van Grieken, R. (Eds.), Wiley.

Sookkai, S., Itthipoonthanakorn, T. and Rodpass, J. (2000). Indoor radon in Chiang Rai province, Thailand. Health Sci. 9: 520-523.

Stogiannidis, E. and Laane, R. (2015). Source characterization of polycyclic aromatic hydrocarbons by using their molecular indices: An overview of possibilities. Rev. Environ. Contam. Toxicol. 234: 49-133. https://doi.org/ 10.1007/978-3-319-10638-0_2

Teixeira, E.C., Mattiuzi, C.D.P., Agudelo-Castañeda, D.M., de Oliveira Garcia, K., and Wiegand, F. (2013). Polycyclic aromatic hydrocarbons study in atmospheric fine and coarse particles using diagnostic ratios and receptor model in urban/industrial region. Environ. Monit. Assess. 185: 9587-9602. https://doi.org/10.1007/ s10661-013-3276-2

Thepanondh, S., Ayers, G.P. and Hooper, M.A. (2005). Analysis of precipitation chemistry in northern Thailand. Clean Air Environ. Qual. 39: 43-47. https://search.infor mit.com.au/documentSummary; $\mathrm{dn}=378101234385415 ; \mathrm{r}$ es=IELNZC

Thepnuan, D., Chantara, S., Lee, C., Lin, N. and Tsai, Y. (2019). Molecular markers for biomass burning associated with the characterization of $\mathrm{PM}_{2.5}$ and component sources during dry season haze episodes in Upper South East Asia. Sci. Total Environ. 658: 708-722. https://doi.org/10.1016/j.scitotenv.2018.12.201 
Titos, G., Lyamani, H., Pandolfi, M., Alastuey, A. and Alados-Arboledas, L. (2014). Identification of fine ( $\left.\mathrm{PM}_{1}\right)$ and coarse $\left(\mathrm{PM}_{10-1}\right)$ sources of particulate matter in an urban environment. Atmos. Environ. 89: 593-602. https://doi.org/10.1016/j.atmosenv.2014.03.001

Tsai, Y.I., Sopajaree, K., Chotruksa, A., Wu, H.C. and Kuo, S.C. (2013). Source indicators of biomass burning associated with inorganic salts and carboxylates in dry season ambient aerosol in Chiang Mai Basin, Thailand. Atmos. Environ. 78: 93-104. https://doi.org/10.1016/j.at mosenv.2012.09.040

Turpin, B.J. and Huntzicker, J.J. (1995). Identification of secondary organic aerosol episodes and quantification of primary and secondary organic aerosol concentrations during SCAQS. Atmos. Environ. 29: 3527-3544. https://doi.org/10.1016/1352-2310(94)00276-Q

Vadrevu, K.P., Lasko, K., Giglio, L. and Justice, C. (2015). Vegetation fires, absorbing aerosols and smoke plume characteristics in diverse biomass burning regions of Asia. Environ. Res. Lett. 10: 105003. https://doi.org/10.1 088/1748-9326/10/10/105003

Vadrevu, K.P., Lasko, K., Giglio, L., Schroeder, W., Biswas, S. and Justice, C. (2019). Trends in vegetation fires in south and southeast Asian Countries. Sci. Rep. 9: 7422. https://doi.org/10.1038/s41598-019-43940-x

Vicente, E.D. and Alves, C.A. (2018). An overview of particulate emissions from residential biomass combustion. Atmos. Res. 199: 159-185. https://doi.org/10.1016/j.atmo sres.2017.08.027

Wang, H. and Shooter, D. (2001). Water-soluble ions of atmospheric aerosols in three New Zealand cities: Seasonal changes and sources. Atmos. Environ. 35: 60316040. https://doi.org/10.1016/S1352-2310(01)00437-X

Wang, L., Du, H., Chen, J., Zhang, M., Huang, X., Tan, H., Kong, L. and Geng, F. (2013). Consecutive transport of anthropogenic air masses and dust storm plume: Two case events at Shanghai, China. Atmos. Res. 127: 22-33. https://doi.org/10.1016/j.atmosres.2013.02.011

Wang, Y., Zhuang, G., Tang, A., Yuan, H., Sun, Y., Chen, S. and Zheng, A. (2005). The ion chemistry of $\mathrm{PM}_{2.5}$ aerosol in Beijing. Atmos. Environ. 39: 3771-3784. https://doi.org/10.1016/j.atmosenv.2005.03.013

Wheeler, A., Zanobetti, A. and Gold, D.R. (2006). The relationship between ambient air pollution and heart rate variability differs for individuals with heart and pulmonary disease. Environ. Health Perspect. 114: 560 567. https://dx.doi.org/10.1289\%2Fehp.8337

Wincent, E., Le Bihanic, F. and Dreij, K. (2016). Induction and inhibition of human cytochrome P4501 by oxygenated polycyclic aromatic hydrocarbons. Toxicol. Res. 5: 788-799. https://doi.org/10.1039/C6TX00004E

Wold, S., Essensen, K. and Geladi, P. (1987). Principal component analysis. Chemom. Intell. Lab. Syst. 2: 37-52. https://doi.org/10.1016/0169-7439(87)80084-9
World Health Organization (WHO) (2000). Air quality guidelines for Europe. 2nd ed. WHO Regional Office for Europe, Copenhagen. https://apps.who.int/iris/handle/10 $665 / 107335$

$\mathrm{Wu}, \mathrm{C}$., Wu, D. and Yu, J.Z. (2019). Estimation and uncertainty analysis of secondary organic carbon using 1 year of hourly organic and elemental carbon data. $J$. Geophys. Res. 124: 2774-2795. https://doi.org/10.1029/ 2018JD029290

Xiao, H.W., Xiao, H.Y., Luo, L., Shen, C.Y., Long, A.M., Chen, L., Long, Z.H. and Li, D.N. (2017). Atmospheric aerosol compositions over the South China Sea: Temporal variability and source apportionment. Atmos. Chem. Phys. 17: 3199-3214. https://doi.org/10.5194/acp-17-3199-2017

Xing, L., Li, G., Pongpiachan, S., Wang, Q., Han, Y., Cao, J., Tipmanee, D., Palakun, J., Aukkaravittayapun, S., Surapipith, V. and Poshyachinda, S. (2020). Quantifying the contributions of local emissions and regional transport to elemental carbon in Thailand. Environ. Pollut. 262: 114272. https://doi.org/10.1016/j.envpol.2020.114272

Yao, X.H., Chan, C.K., Fang, M., Cadle, S., Chan, T., Mulawa, P., He, K. and Ye, B. (2002). The water-soluble ionic composition of $\mathrm{PM}_{2.5}$ in Shanghai and Beijing, China. Atmos. Environ. 36: 4223-4234. https://doi.org/1 0.1016/S1352-2310(02)00342-4

Yttri, K.E., Aas, W., Bjerke, A., Cape, J.N., Cavalli, F. and Ceburnis, D. (2007). Elemental and organic carbon in $\mathrm{PM}_{10}$ : A one year measurement campaign within the European Monitoring and Evaluation Programme EMEP. Atmos. Chem. Phys. 7: 5711-5725. https://doi.org/10.519 4/acp-7-5711-2007

Zhang, M., Chen, J.M., Wang, T., Cheng, T.T., Lin, L., Bhatia, R.S. and Havey, M. (2010). Chemical characterization of aerosols over the Atlantic Ocean and the Pacific Ocean during two cruises in 2007 and 2008. J. Geophys. Res. 115: 1842-1851. https://doi.org/10.1029/ 2010JD014246

Zhang, Q., Gao, R., Xu, F., Zhou, Q., Jiang, G., Wang, T., Chen, J., Hu, J., Jiang, W. and Wang, W. (2014). Role of water molecule in the gas-phase formation process of nitrated polycyclic aromatic hydrocarbons in the atmosphere: A computational study. Environ. Sci. Technol. 48: 5051-5057. https://doi.org/10.1021/es500453g

Zhou, J.L., Fileman, T.W., Evans, S., Donkin, P., Readman, J.W., Mantoura, R.F.C. and Rowland, S. (1999). The partition of fluoranthene and pyrene between suspended particles and dissolved phase in the Humber Estuary: A study of the controlling factors. Sci. Total Environ. 244: 305-321. https://doi.org/10.1016/S0048-9697(99)00404-0

Received for review, March 26, 2020 Revised, June 10, 2020 Accepted, June 15, 2020 